NBER WORKING PAPER SERIES

\title{
RESOURCE CURSE OR DEBT OVERHANG?
}

\author{
Osmel Manzano \\ Roberto Rigobon \\ Working Paper 8390 \\ http://www.nber.org/papers/w8390 \\ NATIONAL BUREAU OF ECONOMIC RESEARCH \\ 1050 Massachusetts Avenue \\ Cambridge, MA 02138 \\ July 2001
}

We would like to thank Daron Acemoglu, Bill Easterly, and Jim Poterba for very useful discussions and comments. Financial support from the Center for Energy and Environmental Policy Research (CEEPR) is gratefully acknowledged. All remaining errors are ours. The views expressed herein are those of the authors and not necessarily those of the National Bureau of Economic Research.

(C) 2001 by Osmel Manzano and Roberto Rigobon. All rights reserved. Short sections of text, not to exceed two paragraphs, may be quoted without explicit permission provided that full credit, including $\subseteq$ notice, is given to the source. 
Resource Curse or Debt Overhang?

Osmel Manzano and Roberto Rigobon

NBER Working Paper No. 8390

July 2001

JEL No. O4

\section{ABSTRACT}

It has been widely believed that resource abundant economies grow less than other economies. In a very influential paper, Sachs and Warner (1997), point out that there is a negative relationship between resource abundance and growth. Two important econometric problems are present in the traditional empirical literature: First, the result might depend on factors that are correlated with primary exports but that have been excluded from the regression. Second, total GDP includes the production in the resource sector that has been declining in the last 30 years. We correct for those issues. Our results indicate that the so called "Natural Resource Curse" might be related to a debt overhang. In the 70's when commodities' prices were high, natural resource abundant countries used them as collateral for debt. The 80 's witnessed an important fall in the prices that drove these countries to debt crises. When we estimate the model taking these into account, we found that the effect of resource abundance disappears.

Osmel Manzano

Unidad de Estudios Económicos

Corporación Andina de Fomento

and Universidad Católica Andrés Bello

omanzano@caf.com
Roberto Rigobon

Sloan School of Management

Massachusetts Institute of Technology

and NBER

rigobon@mit.edu 


\section{Introduction}

This research is based on a widely held belief that resource-abundant economies grow less than other economies. As seen in

Figure 1, this conviction is supported by a simple observation of the growth rate in these countries. This effect was formally estimated in a recent paper by Sachs and Warner [8].

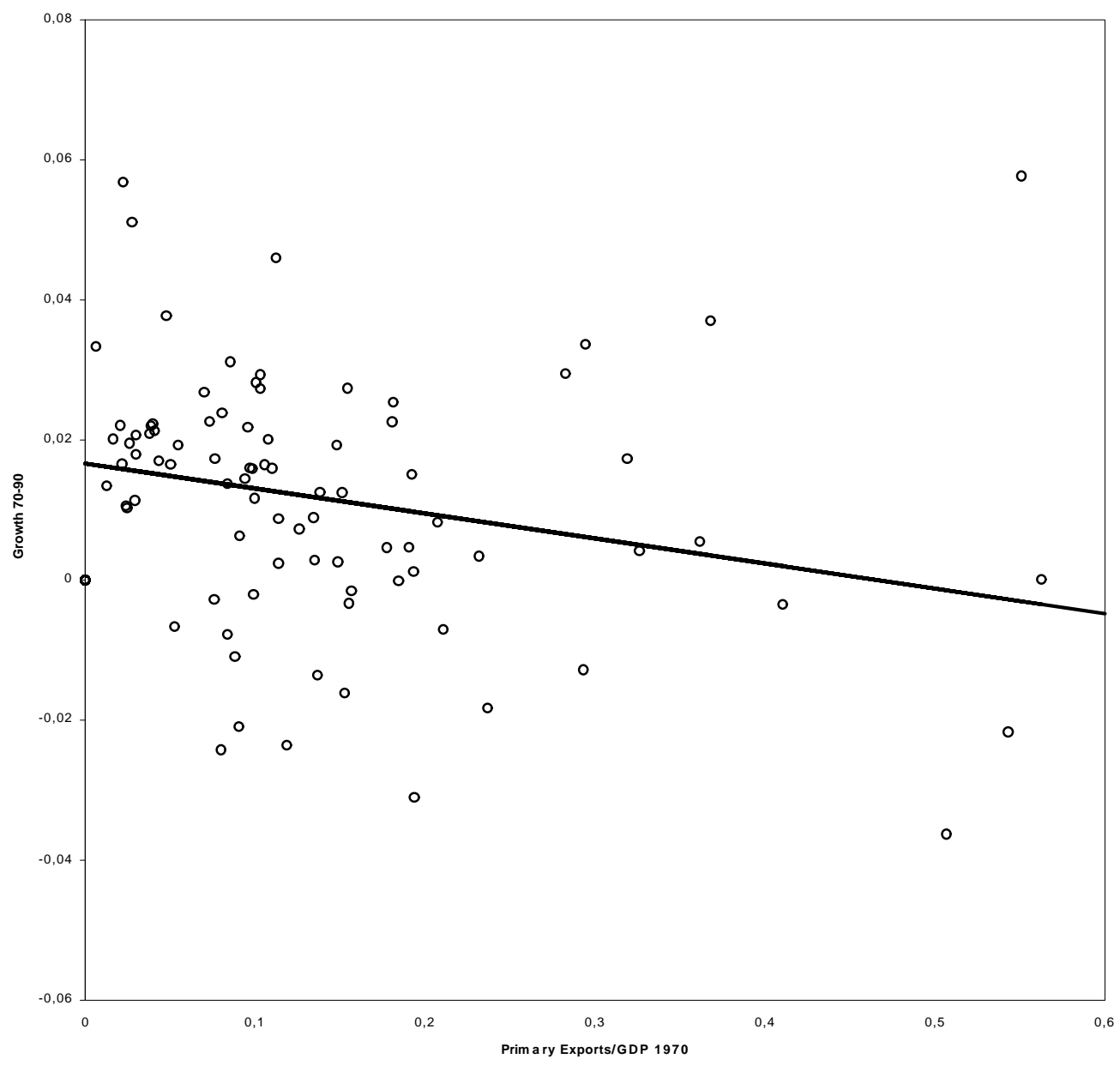

Figure 1: Natural Resource Abundance and Growth 
Their results, shown in Table $1^{1}$, indicate that there is a negative relationship between resource abundance --measured as the share of primary exports to the gross national product (GNP)-- and growth, which is measured as the growth rate for the gross domestic product (GDP) per economically active population. An increase in a country's primary exports equivalent to $1 \%$ of the GNP reduces its growth rate between $0.07 \%$ and $0.10 \%$. In Table 2 we present some examples of this finding, to illustrate the important impact these results have: Tunisia will grow $0.48 \%$ to $1.03 \%$ less than a country with similar income, investment rate, external sector rules and rule of law, but which has no primary exports. This number can be as high as $3.8 \%$ to $5.4 \%$ for countries like Zambia.

Table 1: Results from Sachs and Warner

Results from Sachs and Warner [8] Dependet Variable: Average Annual GDP Growth Rate (1970-89) Log. GDP $70^{b}$ $-.0011$ $(0.55)$ $-.0096$ $(-5.16)$

Prim. Exp./GNP $70^{\mathrm{C}}$ $-.0943$ $-.0696$ $-.0142$ $-.0179$

Years Open $70-89^{d}$ $(-4.75)$ $(-4.55)$ .0306 $(-7.77)$ $(-8.82)$

Years Open 70-89 (8.05) $-.0729$ $(-0.242)$ $-.1026$ $(-6.89)$ $\begin{array}{ll}.0242 & .0134 \\ (7.06) & (3.44)\end{array}$

Log. Investment/GDP 70-89 $.0102 \quad .0081$

Rule of Law ${ }^{f}$ (2.63) .004

Growth in Terms of Trade ${ }^{g}$

Source: Sachs and Warner [8]

${ }^{a}$ Average growth rate for the GDP per economically active population.

${ }^{\mathrm{b}}$ Logarithm of the GDP per economically active population in 1970.

${ }^{\mathrm{c}}$ Share of Primary exports to GNP in 1970.

${ }^{\mathrm{d}}$ Percentage of years open in the period of 1970-1989.

${ }^{\mathrm{e}}$ Average of the period of the logarithm of the investment to output ratio.

${ }^{\mathrm{f}}$ Index that measures the rule of law.

${ }^{g}$ Average growth rate for the terms of trade.

\footnotetext{
${ }^{1}$ The coefficients are the scaling of the coefficients in Table 1 in Sachs and Warner [8]. See Sachs and Warner [8] for a detailed description of the variables.
} 
Table 2: Sample Effects

\begin{tabular}{cll}
\hline \hline Sample Position & Country & Effect \\
\hline $1 \%$ & India & -0.11 to -0.16 \\
& U. S. & -0.09 to -0.13 \\
\hline $50 \%$ & Tunisia & -0.72 to -1.03 \\
& Ecuador & -0.48 to -0.81 \\
\hline $99 \%$ & Malaysia & -2.5 to -3.6 \\
& Guyana & -3.5 to -5.0 \\
& Zambia & -3.8 to -5.4 \\
\hline \hline
\end{tabular}

Source: Authors' calculations based on Table 1.

However, there has been recent literature suggesting evidence to the contrary. For example, Davis [3] finds that natural-resource abundant countries have higher social indicators than other countries, controlling by income. In addition, these countries have higher growth rates for those indicators.

In this paper we further explore the "resource curse" using alternative approaches. We show that the results from Sachs and Warner are not robust for small changes in the econometric procedure. Nevertheless, the effect continues to exist in the cross-sectional, therefore, in the last section of the paper we concentrate on explaining why it remains.

In particular, we argue that in the 70's commodity prices were high, which led developing countries to use them as collateral for debt ${ }^{2}$. The 80 's saw an important fall of those prices, leaving developing countries with an important amount of debt and a low flow of foreign resources to pay them. Thus, in the sample, the cruse (low growth) looks close to a debt-overhang problem.

The paper is organized as follows. In Section 1, we explain the problems associated we growth regressions. Then in Section 2, we reestimate the findings of the literature, using alternative approaches. Section 3 reviews different alternative explanations for the findings. Finally, Section 4 presents our conclusions.

\footnotetext{
${ }^{2}$ We are not saying that there was an explicit use of them as collateral, but most creditors gave loans under the assumption that these countries will have funds to pay back based on their resource wealth.
} 


\section{The Problems of Estimating the "Resource Curse"}

The empirical literature on growth starts from an estimation of the form:

$$
\ln y_{i, t}-\ln y_{i, t-\tau}=\alpha \ln y_{i, t-\tau}+\beta X_{i, t}+\eta_{i}+\varepsilon_{i, t}
$$

Eq 1

where $y_{i, t}$ represents output for country $i$ at period $t, X$ represents a series of variables that explain growth, $\eta_{i}$ is a country specific effect, and $\varepsilon_{i, t}$ represents the error term.

In Sachs and Warner [8], this estimation is done using the total GDP growth as an independent variable for a cross-section of countries. These two issues --the use of total GDP and the use of a cross-section data-- may have an impact on the coefficients estimated.

On one hand, cross-section estimators rely on the assumption that individual effects are uncorrelated with other right-hand-side variables ${ }^{3}$. If there are some unobservable characteristics that are correlated with the right-hand-side variables, the coefficients would be biased. As explained in Caselli et al. [2], this assumption can be violated within the dynamic framework of a growth regression. With a panel this problem can be solved.

On the other hand, total GDP includes the resource sector of the economy. This sector affects total growth, especially when the share of primary exports is high. Therefore it is important to know the behavior of the resource sector.

Table 3 shows the change over time of the per-capita production of 7 commodities. We use per-capita production because this is what the left-hand side of equation (1) tries to capture. The table indicates that the production of natural resources per capita has generally fallen. Only one commodity (gold) has a growth rate in production greater than the average growth rate for the total GDP $(1.1 \%)$ in our sample of countries.

\footnotetext{
${ }^{3}$ In a cross-section regression, there is only one $t$. Therefore, it is needed for $\eta_{\mathrm{i}}$ to be uncorrelated with $\mathrm{X}_{\mathrm{i}}$. Then, the total error term $-\xi_{\mathrm{i}}=\eta_{\mathrm{i}}+\varepsilon_{\mathrm{i}}-$ would be uncorrelated with $\mathrm{X}_{\mathrm{i}}$.
} 
Table 3: Commodity Production per-capita

\begin{tabular}{|c|c|c|c|}
\hline \multicolumn{4}{|c|}{ Average Annual Growth Rate (1978-1996) } \\
\hline \multirow{3}{*}{ Commodity } & \multicolumn{3}{|c|}{ Group } \\
\hline & \multicolumn{3}{|c|}{ Countries with the } \\
\hline & World & Highest Dependency ${ }^{a}$ & Other Countries \\
\hline Oil & -1.5 & $-3.4 b^{b}$ & -0.6 \\
\hline Tin & -1.4 & $-5.9^{c}$ & 4.9 \\
\hline Zinc & -1.0 & $-1.2^{d}$ & -0.9 \\
\hline Lead & -3.1 & $-3.0^{e}$ & -3.2 \\
\hline Silver & -0.1 & $1.3^{f}$ & -0.9 \\
\hline Copper & 0.1 & $-2.3^{g}$ & 1.8 \\
\hline Glod & 1.3 & $-3.8^{\mathrm{h}}$ & 4.9 \\
\hline \multicolumn{4}{|c|}{ Sources: Financial Times [4], OPEC [10], and Summers and Heston [12]. } \\
\hline \multicolumn{4}{|c|}{$\begin{array}{l}\text { a } \text { Countries that had the highest production to GDP ratio in } 1978 . \\
\text { b Actual OPEC Members: Algeria, Indonesia, Iran, Iraq, Kuwait, Libya, Nigeria, Qatar, Saudi } \\
\text { Arabia, United Arab Emirates, Venezuela. } \\
\text { c In order of dependency: Bolivia, Malaysia, Zaire, Rwanda, Thailand, Indonesia. } \\
{ }^{\mathrm{d}} \text { In order: Zaire, Zambia, Peru, Namibia, Ireland, Canada. } \\
\text { e In order: Namibia, Peru, Morocco, Zambia, Canada. } \\
{ }^{\mathrm{f}} \text { In order: Peru, Zaire, Namibia, Chile, Mexico, Dominican Republic. } \\
\text { g In order: Papua New Guinea, Zambia, Zaire, Chile, Peru, Philippines. } \\
\text { h In order South Africa, Papua New Guinea, Zimbabwe, Ghana, Dominican Republic, } \\
\text { Philippines. }\end{array}$} \\
\hline
\end{tabular}

The table also depicts another fact. We divide countries in two groups: the 5 or 6 countries where the ratio of commodity production to GDP is the highest, and the rest of the world. It is clear that, with the exception of lead and silver, the growth rate in production of the countries with the highest dependency has been lower than the rest of the world. These results lead one to ask the question whether previous estimations of the effect of natural resources are just estimations of the fall in per capita production of the resource sector.

\section{A Re-estimation}

For the reasons given in the previous section, in this section we reestimate Sachs and Warner [8]. First, we will use panel estimation and then, we will use different measures of the nonresource side of the economy. 


\subsection{A Panel Estimation}

In order to estimate a panel, we need to obtain a different data set than Sachs and Warner [8]. ${ }^{4,5}$ Table 4 compares the result from Sachs and Warner $[8]^{6}$ with the result of doing the same cross-section analysis using our data set. It is clear the results are statistically the same.

Table 4: Sample Selection

\begin{tabular}{|c|c|c|}
\hline \multicolumn{3}{|c|}{ Dependent Variable: Average Annual GDP Growth Rate } \\
\hline & Sachs and & This \\
\hline & Warner & Sample \\
\hline Log. GDP 70 & $\begin{array}{c}-.0134 \\
(-7.77)\end{array}$ & $\begin{array}{l}-.0135 \\
(-6.698)\end{array}$ \\
\hline Prim. Exp./GNP & $\begin{array}{c}-.0729 \\
(-5.57)\end{array}$ & $\begin{array}{l}-.0700 \\
(-5.667)\end{array}$ \\
\hline Years Open 70-90 & $\begin{array}{c}0.0242 \\
(7.60)\end{array}$ & $\begin{array}{c}0.0235 \\
(6.028)\end{array}$ \\
\hline Log. Invest./GDP 70-89 & $\begin{array}{c}0.0125 \\
(5.63)\end{array}$ & $\begin{array}{l}0.0140 \\
(5.540)\end{array}$ \\
\hline $\mathrm{N}$ & 87 & 79 \\
\hline$R^{2}$ & 0.67 & 0.65 \\
\hline
\end{tabular}

We estimate a panel using alternative data sets, one with at least 2 time elements and the other with 4 time elements. The results are shown in Table 5. The first set of regressions, from (1.1) to (1.3), indicates that the effect is statistically significant in the cross-section of this sub-sample but insignificant in a panel with fixed effects. The same is done in columns (2.1) to (2.3) using the sample with 4 time elements. This allows for the presence of more observations to calculate the fixed effect, but there are less countries with information available to do this regression. Again, the effect is statistically significant in the cross-section -though only at the $2.5 \%$ level-- and then insignificant in a panel with fixed effects.

\footnotetext{
${ }^{4}$ In Appendix A, we explain in detail some sample selection issues that drive this fact.

${ }^{5}$ In Appendix D we describe the data used for this chapter

${ }^{6}$ The reader will note that we chose regression number (1.3) of Table 1. The reason is that the Rule of Law is a "onetime" variable and therefore will not be useful for panel estimation, and that the Change in Terms of Trade was not significant in column (1.4).
} 
Table 5: Effect of Natural Resources: Cross-Section vs. Panel

\begin{tabular}{|c|c|c|c|c|c|c|}
\hline \multicolumn{7}{|c|}{ Dependent Variable: Average Annual GDP Growth Rate } \\
\hline & \multicolumn{3}{|c|}{$\begin{array}{l}\text { Using sample where a panel } \\
\text { with } T=2 \text { can be estimated }\end{array}$} & \multicolumn{3}{|c|}{$\begin{array}{l}\text { Using sample where a panel } \\
\text { with } \mathrm{T}=4 \text { can be estimated }\end{array}$} \\
\hline & & & & & & \\
\hline & Cross-Sctn & Pooled & Fx.Ef. & Cross-Sctn & Pooled & Fx.Ef. \\
\hline Prim. Exp./GNP & $\begin{array}{l}-.0636^{*} \\
(-4.578)\end{array}$ & $\begin{array}{l}-.0565^{\star} \\
(-3.796)\end{array}$ & $\begin{array}{l}-.0015 \\
(-0.051)\end{array}$ & $\begin{array}{l}-.0454^{\star *} \\
(-2.346)\end{array}$ & $\begin{array}{l}-.01963 \\
(-1.037)\end{array}$ & $\begin{aligned} .0669^{* \star \star} \\
(1.786)\end{aligned}$ \\
\hline Log. GDP 70 & $\begin{array}{l}-.0136^{*} \\
(-6.687)\end{array}$ & $\begin{array}{l}-.0153^{\star} \\
(-5.679)\end{array}$ & $\begin{array}{l}-.0720^{*} \\
(-7.995)\end{array}$ & $\begin{array}{l}-.0154^{*} \\
(-6.726)\end{array}$ & $\begin{array}{l}-.0208^{*} \\
(-6.776)\end{array}$ & $\begin{array}{l}-.0811^{*} \\
(-7.672)\end{array}$ \\
\hline \%Years Open 70-90 & $\begin{array}{l}.0247^{*} \\
(6.223)\end{array}$ & $\begin{array}{l}.0197^{\star} \\
(3.954)\end{array}$ & $\begin{array}{l}-.0124 \\
(-1.043)\end{array}$ & $\begin{array}{l}.0252^{*} \\
(6.420)\end{array}$ & $\begin{array}{l}.0255^{\star} \\
(5.597)\end{array}$ & $\begin{array}{l}.0246^{* *} \\
(2.576)\end{array}$ \\
\hline Log. Invest./GDP 70-89 & $\begin{array}{l}.0140^{*} \\
(5.514)\end{array}$ & $\begin{array}{c}0190^{*} \\
(5.783)\end{array}$ & $\begin{array}{l}.0199^{* *} \\
(2.003)\end{array}$ & $\begin{array}{l}.0126^{*} \\
(3.715)\end{array}$ & $\begin{array}{l}.0220^{*} \\
(5.335)\end{array}$ & $\begin{array}{l}.0477^{*} \\
(4.698)\end{array}$ \\
\hline Hausman Test & & & 63,52 & & & 50,78 \\
\hline F Test all $u_{i}=0$ & & & 2,11 & & & 1,98 \\
\hline Obs & 74 & 148 & 148 & 54 & 216 & 216 \\
\hline $\mathrm{N}$ & 74 & 74 & 74 & 54 & 54 & 54 \\
\hline $\mathrm{T}$ & 1 & 2 & 2 & 1 & 4 & 4 \\
\hline
\end{tabular}

t-statistics in parenthesis.

*,**,*** imply significant at the 1,5 and $10 \%$ level.

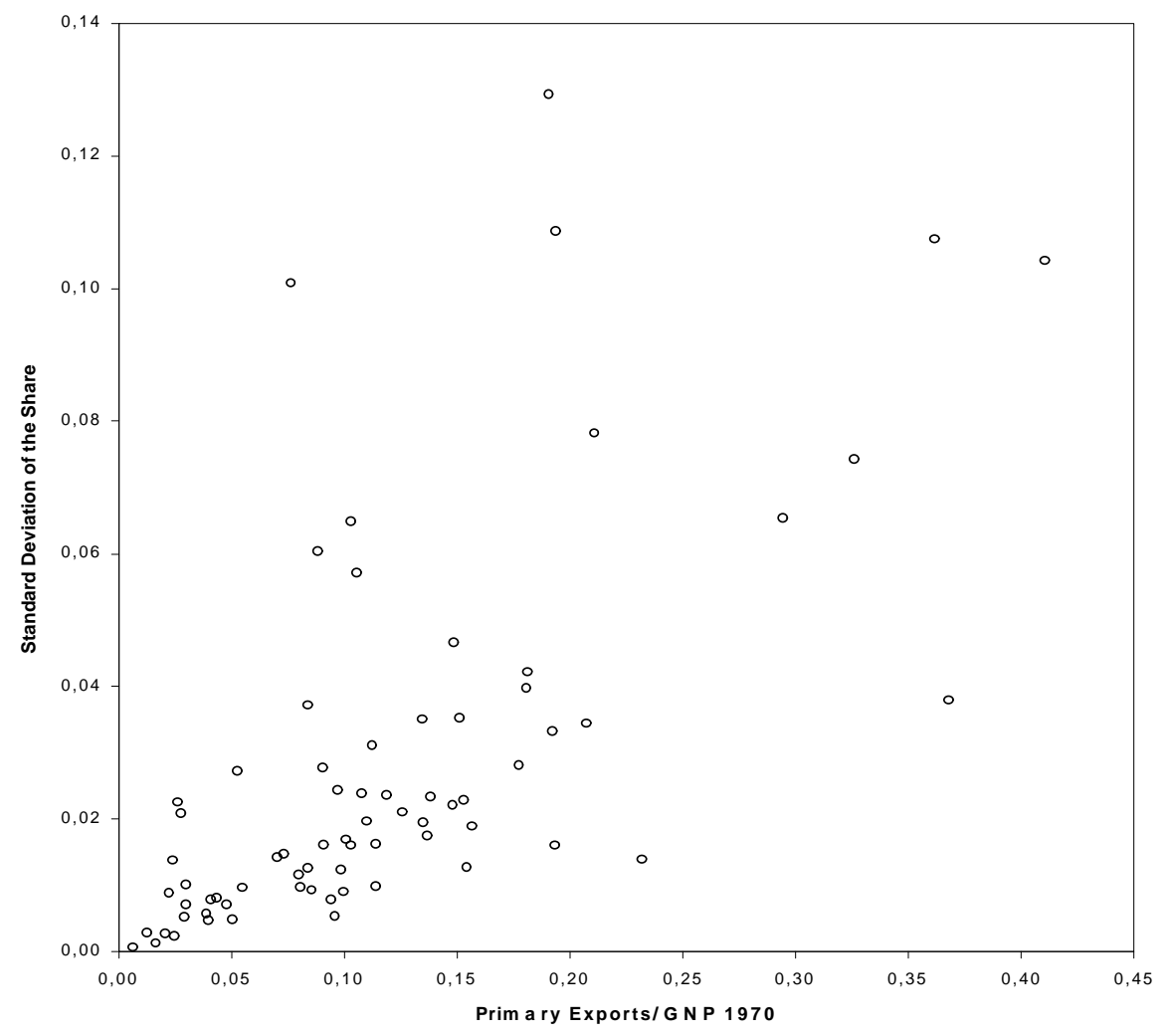

Figure 2: Shocks to Primary Exports 
It is important to mention that the effects of the other variables do remain significant even after the panel is done, with the expected signs and even with the expected relative size. ${ }^{7}$ The fact that the impact of resource abundance disappears once fixed effects are introduced implies that this variable is correlated with unobservable characteristics and therefore it disappears once fixed effects are introduced.

A natural concern is to ask whether we are just estimating the fixed effects of a country's resource richness, a fact that is time invariant. In Figure 2, we show the shocks to the share (measured through the standard deviation) compared to the share in 1970. We see that the biggest shocks are not concentrated on the biggest producers. On the other hand, the cross-section measures the ranking of the countries from low exporters to high exporters. In this sample it changes from period to period. ${ }^{8}$

Summarizing, in the panel we see that there are no effects from primary exports change through time, which cast some doubts on the validity of the conclusions derived from the crosssectional regressions.

\subsection{Growth in the Non-Resource Sector}

In this subsection we deal with the other issue related to the estimation of the effect of resource abundance, namely the inclusion of the resource sector on the total GDP. For that purpose, we will use alternative measures for the non-resource side of the economy. In general, the effect still remains present for the cross-section but disappears with the fixed effects.

Throughout this section we will determine whether the effect found by Sachs and Warner [8] on total GDP is still present in the sub-sample for which data is available for the non-resource sector. Then, we estimate the effect on the non-resource measure of the economy. Finally, we reestimate the effect on a panel. In this section we only present the results for the panels of 10-year

\footnotetext{
${ }^{7}$ For example the coefficient on the lagged GDP is expected to be greater the shorter the period of time where growth is measured. For an explanation see Barro and Sala-i-Martin [1].

${ }^{8}$ See in Appendix B.
} 
periods. The reason for this is that when a panel of 5-year periods is used the negative effect of natural resources is lost even in the cross-sections.

For the non-resource sector of the economy we construct a measure represented by the GDP net of resource exports. Arguably, this tends to eliminate the resource sector in those countries where the sector is large relative to the rest of the economy. ${ }^{9}$

In Table 6, we show the cross-section results. It is clear that the effect measured by Sachs and Warner is still present in this sub-sample. The coefficients in column (1) are actually not significantly different from those in Table 4 . Then we proceed to repeat the estimation with the non-resource side of the economy. The results in column (2) seem to suggest that there is a negative effect on growth in the non-resource side of the economy coming from resource abundance, similar to the results presented in the previous subsection.

Table 6: Non-Resource Growth: Cross Section

\begin{tabular}{lcc}
\hline \hline \multicolumn{3}{c}{ Dependent Variable: Average Annual GDP Growth Rate } \\
\hline & $\begin{array}{c}\text { Using } \\
\text { Total GDP }\end{array}$ & $\begin{array}{c}\text { Using } \\
\text { Non-Resource GDP }\end{array}$ \\
\cline { 2 - 3 } Prim. Exp./GNP & -.0763 & -.0643 \\
& $(-5.677)$ & $(-4.409)$ \\
Log. GDP 70 & -.0123 & -.0130 \\
& $(-6.186)$ & $(-6.002)$ \\
Years Open 70-90 & 0.0233 & 0.0275 \\
& -5.667 & $(6.157)$ \\
Log. Invest./GDP 70-89 & 0.0114 & 0.0090 \\
& $(4.583)$ & $(3.349)$ \\
\hline \multicolumn{1}{c}{$\mathrm{N}$} & 66 & 66 \\
$\mathrm{R}^{2}$ & 0.61 & 0.56 \\
\hline \hline t-statistics in parenthesis. &
\end{tabular}

In Table 7, the results from the estimation of the effect on a panel are given. As in previous tables, we started with the cross-section to determine whether the effect is present or not. It is, but

\footnotetext{
${ }^{9}$ See Appendix C for alternative measures of the non-resource sector. The results are qualitatively the same.
} 
is only weakly significant. ${ }^{10}$ Again, as in the previous estimations, the effect disappears once a panel with fixed effects is done.

Table 7: Non-Resource GDP: Cross-Section vs. Panel

\begin{tabular}{|c|c|c|c|}
\hline \multicolumn{4}{|c|}{ Dependent Variable: Average Annual GDP Growth Rate } \\
\hline & & & \\
\hline & Cross-Sctn & Pooled & Fx.Ef. \\
\hline Prim. Exp./GNP & $\begin{array}{c}-.0401^{* *} \\
(-2.44)\end{array}$ & $\begin{array}{l}-.0351^{* *} \\
(-2.061)\end{array}$ & $\begin{array}{l}.0061 \\
(0.175)\end{array}$ \\
\hline Log. GDP 70 & $\begin{array}{l}-.0126^{*} \\
(-5.796)\end{array}$ & $\begin{array}{c}-.0139^{\star} \\
(-4.879)\end{array}$ & $\begin{array}{l}-.0785^{\star} \\
(-6.468)\end{array}$ \\
\hline \%Years Open 70-90 & $\begin{array}{l}.0261^{*} \\
(5.840)\end{array}$ & $\begin{array}{l}.0256^{*} \\
(4.607)\end{array}$ & $\begin{array}{l}.0008 \\
(0.055)\end{array}$ \\
\hline Log. Invest./GDP 70-89 & $\begin{array}{l}.0100^{*} \\
(3.815)\end{array}$ & $\begin{array}{l}. ' 0117^{*} \\
(3.384)\end{array}$ & $\begin{array}{c}.0007 \\
(0.046)\end{array}$ \\
\hline Hausman Test & & & 34.58 \\
\hline F Test all $u_{i}=0$ & & & 1.27 \\
\hline Obs & 58 & 116 & 116 \\
\hline $\mathrm{N}$ & & 58 & 58 \\
\hline $\mathrm{T}$ & & 2 & 2 \\
\hline
\end{tabular}

t-statistics in parenthesis.

${ }^{*},{ }^{* *},{ }^{* * *}$ imply significant at the 1,5 and $10 \%$ level.

In the previous estimations we construct the "non-resource GDP" with the nominal share of primary exports to GNP. If relative prices change considerably, this can affect the estimation. Ideally, this should be corrected by using the respective deflators. However, there are no deflators just for primary exports. For that reason, we repeat the construction of this "non-resource GDP" taking into account changes in relative prices using the deflator for total exports compared to the GDP deflator. It can be expected that the deflator for total exports captures the change in prices for primary exports in countries where primary products are the main export. For purposes of abbreviation, we will call this variable the "real" non-resource growth. ${ }^{11}$

The cross-section estimations are shown in Table 8. Column (1) shows that the effect is still present in this sub-sample. Then, in column (2), we see that the negative effect persists on the

\footnotetext{
${ }^{10}$ Both p-values are actually lower than $2.5 \%$.

${ }^{11}$ This does not mean that the previous measure of "net-of-exports" GDP was nominal. It was also based on the real GDP, but without taking into account the change of relative prices inside a country.
} 
"real" non-resource side of the economy, even with a bigger impact than in any other previous estimation.

Table 8: "Real" Non-Resource Growth: Cross-Section

\begin{tabular}{lcc}
\hline \hline \multicolumn{3}{c}{ Dependent Variable: Average Annual GDP Growth Rate } \\
\hline & $\begin{array}{c}\text { Using } \\
\text { Total GDP }\end{array}$ & $\begin{array}{c}\text { Using } \\
\text { Non-Resource GDP }\end{array}$ \\
\cline { 2 - 3 } Prim. Exp./GNP & -.0535 & -.1117 \\
& $(-3.585)$ & $(-2.959)$ \\
Log. GDP 70 & & \\
& -.0114 & -.0259 \\
Years Open 70-90 & $(-5.617)$ & $(-5.036)$ \\
& 0.0226 & 0.0569 \\
Log. Invest./GDP 70-89 & $(-5.396)$ & $(5.377)$ \\
& 0.0116 & 0.0164 \\
$\mathrm{~N}$ & $(4.794)$ & $(2.683)$ \\
\hline $\mathrm{R}^{2}$ & 61 & 61 \\
\hline \hline
\end{tabular}

t-statistics in parenthesis.

All coefficents are significant at any level

The next step is to do the panel estimations. There are two different ways to do this regression: one is to continue to use the nominal share of primary exports to GDP as an explanatory variable, and the other is to use the real share. Both are used in Table 9. These alternative measures have different interpretations: the former measures the "windfall" effect, while the latter measures the presence and activity of a resource sector. In other words, a shock in the first one will measure a price windfall, while a shock in the second one will measure the discovery of new reserves. 
Table 9: "Real" Non-Resource GDP: Cross-Section vs. Panel

\begin{tabular}{|c|c|c|c|c|c|}
\hline \multicolumn{6}{|c|}{ Dependent Variable: Average Annual GDP Growth Rate } \\
\hline & \multirow[b]{3}{*}{ Cross-Sctn } & \multicolumn{4}{|c|}{ Panel } \\
\hline & & \multicolumn{2}{|c|}{ Using nominal shares } & \multicolumn{2}{|c|}{ Using "real" shares } \\
\hline & & Pooled & Fx.Ef. & Pooled & Fx.Ef. \\
\hline Prim. Exp./GNP & $\begin{array}{l}-.0894^{\star \star} \\
(-2.326)\end{array}$ & $\begin{array}{c}-.0210 \\
(-1.042)\end{array}$ & $\begin{array}{c}.0456 \\
(1.396)\end{array}$ & $\begin{array}{c}-.0378^{\star \star \star} \\
(-1.705)\end{array}$ & $\begin{array}{l}.0678^{\star \star \star} \\
(1.810)\end{array}$ \\
\hline Log. GDP 70 & $\begin{array}{l}-.0249^{\star} \\
(-4.748)\end{array}$ & $\begin{array}{l}-.0134^{*} \\
(-3.956)\end{array}$ & $\begin{array}{l}-.0884^{*} \\
(-8.763)\end{array}$ & $\begin{array}{l}-.0141^{*} \\
(-4.190)\end{array}$ & $\begin{array}{c}-.08271^{\star} \\
(-8.105)\end{array}$ \\
\hline \%Years Open 70-90 & $\begin{array}{l}.0529^{*} \\
(4.899)\end{array}$ & $\begin{array}{l}.0259^{\star} \\
(3.809)\end{array}$ & $\begin{array}{l}-.0032 \\
(-0.220)\end{array}$ & $\begin{array}{l}.0260^{*} \\
(3.981)\end{array}$ & $\begin{array}{l}-.0043 \\
(0.295)\end{array}$ \\
\hline Log. Invest./GDP 70-89 & $\begin{array}{l}.0172^{*} \\
(2.870)\end{array}$ & $\begin{array}{l}0100^{*} \\
(2.454)\end{array}$ & $\begin{array}{l}.0101 \\
(0.694)\end{array}$ & $\begin{array}{l}.0107^{*} \\
(2.687)\end{array}$ & $\begin{array}{c}.0061 \\
(0.4428)\end{array}$ \\
\hline $\begin{array}{l}\text { Hausman Test } \\
\mathrm{F} \text { Test all } \mathrm{u}_{\mathrm{i}}=0\end{array}$ & & & $\begin{array}{c}69,29 \\
2.26\end{array}$ & & $\begin{array}{l}85.09 \\
2.29\end{array}$ \\
\hline Obs & 56 & 112 & 112 & 112 & 112 \\
\hline $\begin{array}{l}\mathrm{N} \\
\mathrm{T}\end{array}$ & & $\begin{array}{c}56 \\
4\end{array}$ & $\begin{array}{c}56 \\
4\end{array}$ & $\begin{array}{c}56 \\
4\end{array}$ & $\begin{array}{c}56 \\
4\end{array}$ \\
\hline
\end{tabular}

t-statistics in parenthesis.

${ }^{*}{ }^{* \star},{ }^{* * *}$ imply significant at the 1,5 and $10 \%$ level.

As in the previous regressions, we start with the cross-sections to check whether the effect is present in the sample or not. In order to compute the real shares, a base year has to be chosen. We chose 1970; for that reason we only need to do one cross-section. In Table 9 we see that the effect is present in the respective cross-sections --although weak ${ }^{12}$ However, it disappears in both panels. Moreover, the result from column (3.2) suggests a positive sign. ${ }^{13}$

As in subsection 2.1, there is the concern that once we control for changes in relative prices, the only fixed effect is whether a country is resource rich or not, and that variable does not change over time. For that reason, in Table 10 we show the shocks to the "real" primary exports. We see that it is similar to Figure 2, in that the biggest shocks are not concentrated on the biggest producers. On the other hand, there is also a shift in the ranking of the countries. ${ }^{14}$ This reflects the

\footnotetext{
12 The actual p-value is $2.4 \%$.

${ }^{13}$ These results also appears in Appendix C.

${ }^{14}$ See Figure II in Appendix B.
} 
facts presented in the introduction of this section, where we show that the production of commodities is shifting among countries.

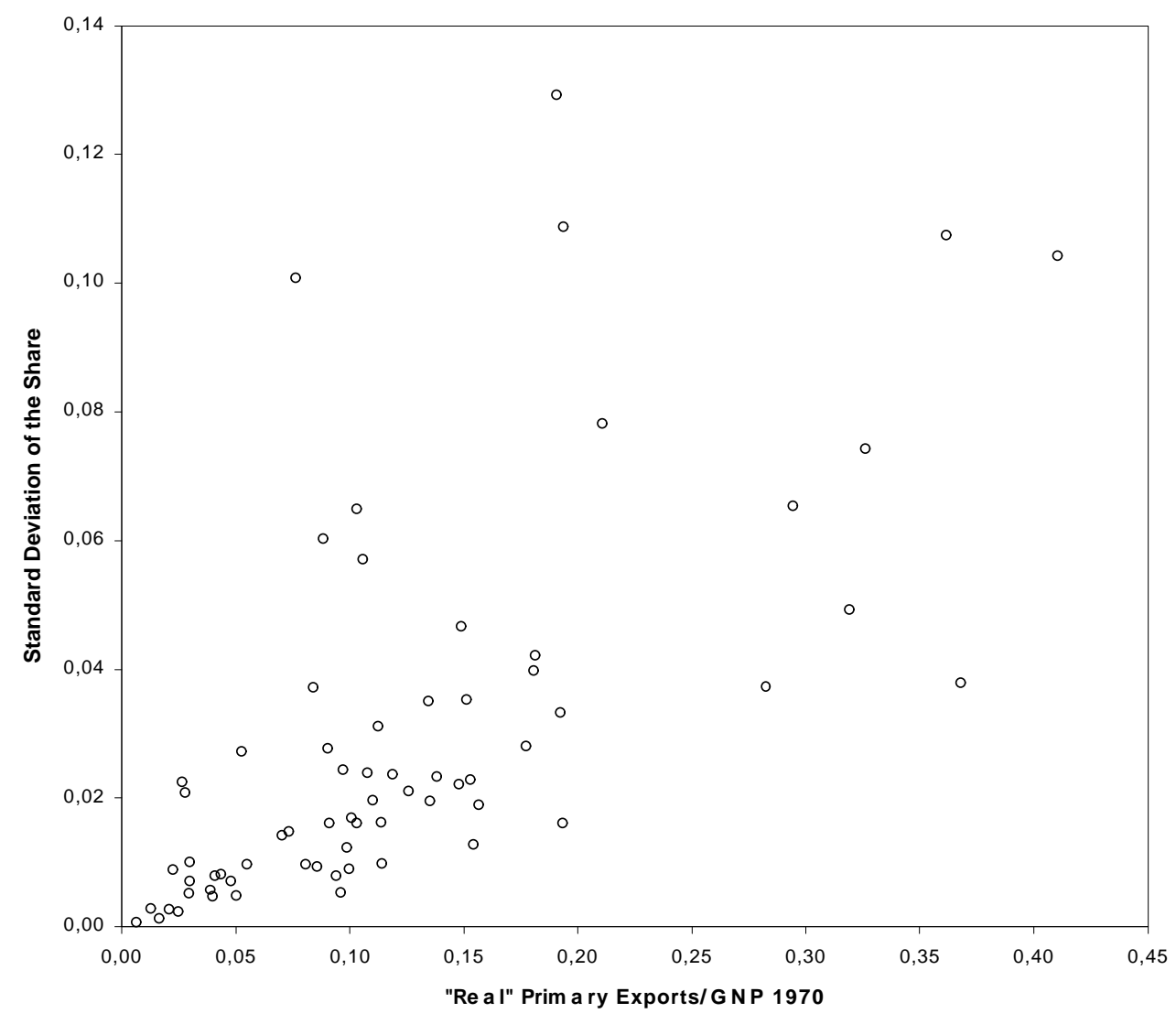

Figure 3: Shocks to "Real" Primary Exports

In this subsection we reestimate the resource curse, using different approaches to measure the non-resource side of the economy. We have found that there is a negative effect present in the cross-section but not in the panels. As in subsection 2.1, the fact that the effect of resource abundance disappears once fixed effects are introduced implies that this variable is correlated with unobservable characteristics and therefore it disappears once fixed effects are introduced. 


\subsection{Dividing Resources by Origin}

An important question to ask is whether the effect is the same for all kinds of primary exports. Primary exports add agricultural, food, mineral and fuel exports together. Clearly, these are very different products with different profitability, different behavior over time, etc. We divide exports into account so in Table 10.

In column (2) we divide primary exports between agricultural ${ }^{15}$ and non-agricultural exports. In column (3) we divide the non-agricultural exports into minerals and fuels. The table shows that once exports are divided into categories, they have different effects. This reinforces the idea that using non-resources GDP is the right approach to see the effects of resource abundance.

Table 10: Dividing Exports by Origin

\begin{tabular}{|c|c|c|c|}
\hline \multicolumn{4}{|c|}{ Dependent Variable: Average Annual GDP Growth Rate } \\
\hline & (1) & $(2)$ & (3) \\
\hline Prim. Exp./GNP & $\begin{array}{l}-.0643^{*} \\
(-4.409)\end{array}$ & & \\
\hline Agr. Exp./GNP & & $\begin{array}{c}-.0287 \\
(-1.583)\end{array}$ & $\begin{array}{c}-.0271 \\
(-1.500)\end{array}$ \\
\hline Non-Agr. Exp./GNP & & $\begin{array}{l}-.1081^{*} \\
(-5.407)\end{array}$ & \\
\hline Fuel Exp./GNP & & & $\begin{array}{c}-.0669^{\star * *} \\
(-1.825)\end{array}$ \\
\hline Min. Exp./GNP & & & $\begin{array}{l}-.1227^{\star} \\
(-5.414)\end{array}$ \\
\hline Log. GDP 70 & $\begin{array}{c}-.0130^{*} \\
(-6.002)\end{array}$ & $\begin{array}{c}-.0121^{*} \\
(-5.851)\end{array}$ & $\begin{array}{c}-.0127^{*} \\
(-6.004)\end{array}$ \\
\hline Years Open 70-90 & $\begin{array}{l}0.0275^{\star} \\
(6.157)\end{array}$ & $\begin{array}{l}0.0247^{\star} \\
(5.717)\end{array}$ & $\begin{array}{c}0.0265^{\star} \\
(5.891)\end{array}$ \\
\hline Log. Invest./GDP 70-89 & $\begin{array}{c}0.0090^{*} \\
(3.349)\end{array}$ & $\begin{array}{l}0.0113^{*} \\
(4.273)\end{array}$ & $\begin{array}{c}0.0110^{*} \\
(4.178)\end{array}$ \\
\hline$\underset{\substack{\mathrm{N} \\
\text { Hausman }}}{\mathrm{N}}$ & 66 & $\begin{array}{c}66 \\
23.22 \\
0.000\end{array}$ & $\begin{array}{c}66 \\
7.88 \\
0.096\end{array}$ \\
\hline Adj. $R^{2}$ & 0.56 & 0.61 & 0.61 \\
\hline
\end{tabular}

${ }^{15}$ Agricultural exports include raw materials and food. 
However, this result has the same properties as all of the previous results in this research. In Table 11, we show that, as in Section 2.1, once a panel with fixed effects is done, the effect becomes insignificant.

Table 11: Effects of Different Resource Exports: Cross-Section vs. Panel

\begin{tabular}{|c|c|c|c|}
\hline \multicolumn{4}{|c|}{$\begin{array}{l}\text { Dependent Variable: Average Annual GDP Growth Rate } \\
\text { for Non-Resource GDP }\end{array}$} \\
\hline & \multirow[b]{2}{*}{$\begin{array}{l}\text { Cross-Sctn } \\
\text { (1) }\end{array}$} & \multicolumn{2}{|c|}{ Panel } \\
\hline & & $\begin{array}{l}\text { Pooled } \\
\text { (2) }\end{array}$ & $\begin{array}{c}\text { Fx.Ef. } \\
(3)\end{array}$ \\
\hline \multirow[t]{2}{*}{ Non-Agr.Exp./GNP } & $-.0899^{\star}$ & $-.0499^{\star}$ & .0079 \\
\hline & $(-4.319)$ & $(0.722)$ & $(1.151)$ \\
\hline \multirow[t]{2}{*}{ Agricultural Exp./GNP } & .0026 & .0211 & .1011 \\
\hline & $(-2.448)$ & $(-2.794)$ & $(0.227)$ \\
\hline \multirow[t]{2}{*}{ Log.GDP } & $-.0117^{\star}$ & $-.0128^{\star}$ & $-.0747^{*}$ \\
\hline & $(-5.814)$ & $(-4.502)$ & $(-5.965)$ \\
\hline \multirow[t]{2}{*}{ \%Years Open } & $.0222^{*}$ & $.0225^{\star}$ & .0054 \\
\hline & $(5.231)$ & $(4.004)$ & $(0.339)$ \\
\hline \multirow[t]{2}{*}{ Log.Inv./GDP } & $.0127^{*}$ & $.0134^{*}$ & .0010 \\
\hline & (5.062) & (3.874) & $(0.063)$ \\
\hline Hausman Test & & & 10.23 \\
\hline F Test all $u=0$ & & & 1.20 \\
\hline Obs & 58 & 116 & 116 \\
\hline $\mathrm{N}$ & & 58 & 58 \\
\hline $\mathrm{T}$ & & 2 & 2 \\
\hline
\end{tabular}

\section{New Dimensions of the "Curse"}

The previous section makes clear that important econometric inconveniences are present in the original formulation of the "curse". There are two striking facts that can be derived from the previous exercises: First, in all specifications, when fixed effects are included, invariable the natural resource curse disappears. Second, however, also in almost all specifications the curse exists in the cross-sectional.

In this section, we tackle this second fact: why we have the effect in the cross-section. An explanation could be that most of the source of variation is found in the cross-sectional and not on 
the time series variation. A second one, already mentioned above, the coefficient in the crosssection may be reflecting the fact that there is a correlation between omitted variables and resource abundance. In this section we will attempt to find those omitted variables.

The first step is to see which are the countries driving the results. We are going to use the specification in column (3) of Table 10 given that the result is clearly driven by non-agricultural exports. For that reason, in Figure 4, we plot the residuals of doing that regression with all variables but the non-agricultural exports against those non-agricultural exports. We see clearly two groups of countries: one that almost draw a "cone" on the upper left hand side and other on the lower right hand side of the graph, that seems to be the group of countries driving the results.

\section{First candidates.}

In this sub-section, we show that the results are not driven by de degree of development, nor by the quality of the institutions,

A first intuitive explanation is to argue that the cross-section is estimating a difference between developed economies and non-developed economies. In Table 12 we repeat the regression done in column (3) of Table 10, and then divide the sample between OECD countries and nonOECD countries. At the bottom of the table are some summary statistics for the share of primary exports in each sub-sample. 


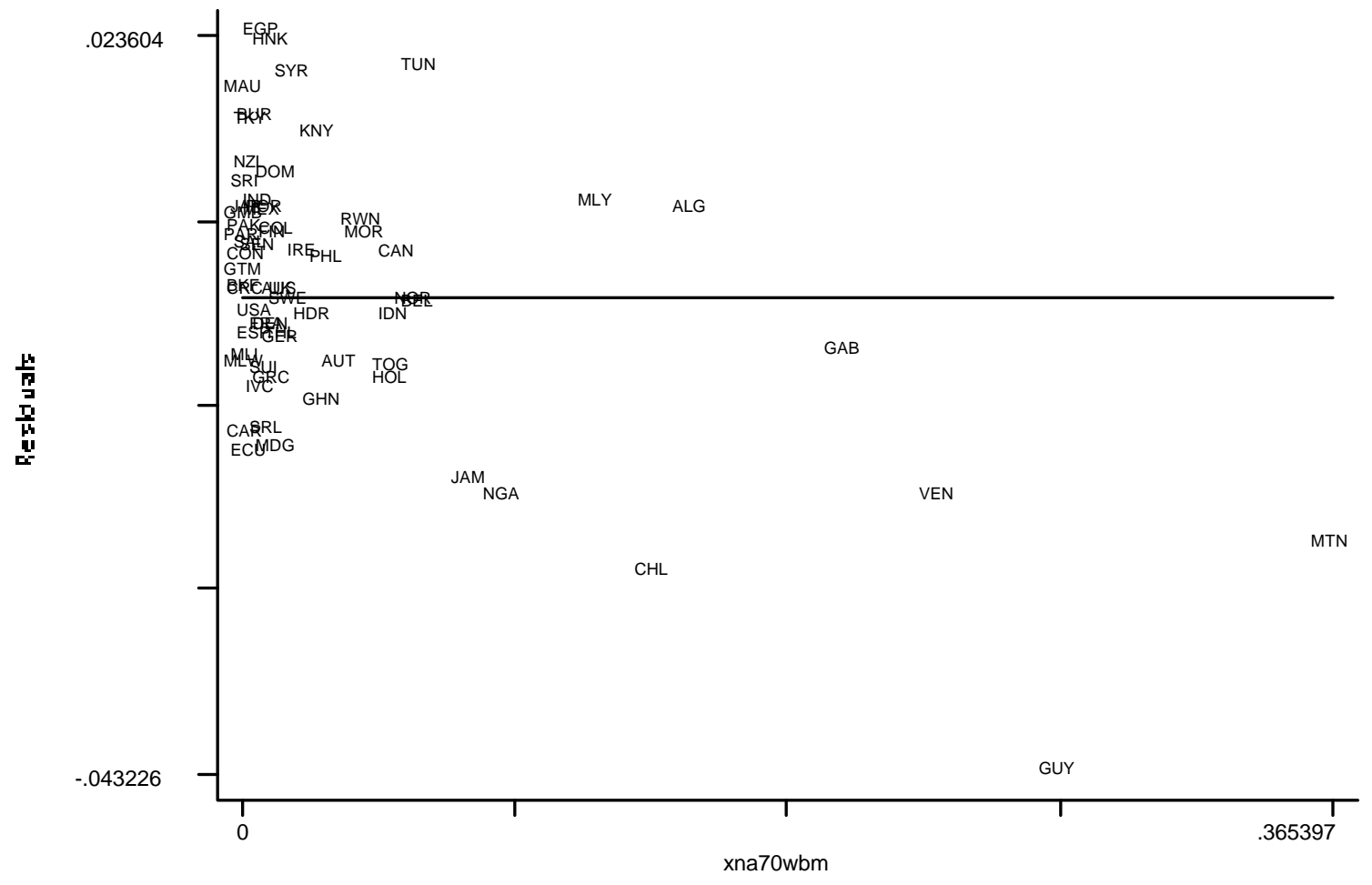

Figure 4: Residuals and Non-Agr. Primary Exports

Non-OECD countries have a higher share of primary exports. On the other hand, this variable does not seem to have an effect on growth in OECD countries. However, there is less variance in the share of primary exports in OECD economies. Also we see that the variable is still significant in non-OECD countries. Consequently, this variable is not just estimating a difference between OECD and non-OECD economies.

An alternative is to check for variables that measure the institutional setting of a country. We are going to focus on the variable that tries to measure the quality of bureaucracy. ${ }^{16} 17$ This variable is measured between 0 and 6 . A high value means low bureaucracy quality. Since it is

\footnotetext{
${ }^{16}$ See Appendix F for a complete description of this variable.

${ }^{17}$ In Appendix D we repeat the regressions from this section with alternative institutional variables. These variables are intended to describe corruption, rule of law, risk of expropriation and risk of government repudiation. There is a problem with these variables however: The methodology to construct them is the same for all. For that reason we do not introduce all of them in the same regression.

These other variables usually have the expected sign but their significance level is lower.
} 
usually measured at a point in time, this variable can be used in panels only before the introduction of fixed effects.

Table 12: Grouping Countries

\begin{tabular}{|c|c|c|c|}
\hline \multicolumn{4}{|c|}{ Dependent Variable: Average Annual GDP Growth Rate } \\
\hline & \multicolumn{3}{|c|}{ Sample } \\
\hline & $\begin{array}{c}\text { Total } \\
(1)\end{array}$ & $\begin{array}{l}\text { OECD } \\
(2)\end{array}$ & $\begin{array}{l}\text { Non-OECD } \\
\text { (3) }\end{array}$ \\
\hline Non-Agr. Exp./GNP & $-.1081^{*}$ & -.0211 & $-.1089^{\star}$ \\
\hline & $(-5.407)$ & $(-0.390)$ & $(-4.116)$ \\
\hline Agr. Exp./GNP & $\begin{array}{l}-.0287 \\
(-1.583)\end{array}$ & $\begin{array}{c}-.0234 \\
(-1.212)\end{array}$ & $\begin{array}{l}-.0334 \\
(-1.352)\end{array}$ \\
\hline Log. GDP 1970 & $\begin{array}{l}-.0121^{*} \\
(-5.851)\end{array}$ & $\begin{array}{l}-.0148^{*} \\
(-4.203)\end{array}$ & $\begin{array}{l}-.0114^{*} \\
(-4.898)\end{array}$ \\
\hline \%Years Open & $\begin{array}{l}0.0247^{*} \\
(5.717)\end{array}$ & $\begin{array}{l}.0161^{*} \\
(3.672)\end{array}$ & $\begin{array}{c}.0284 \\
(4.501)\end{array}$ \\
\hline Log. Invest./GDP (Averge 79-90) & $\begin{array}{l}0.0113^{*} \\
(4.273)\end{array}$ & $\begin{array}{l}.0132^{\star \star *} \\
(2.0271)\end{array}$ & $\begin{array}{l}.0107^{*} \\
(3.922)\end{array}$ \\
\hline $\begin{array}{c}\mathrm{N} \\
\text { Adj. } \mathrm{R}^{2}\end{array}$ & $\begin{array}{c}66 \\
0.61\end{array}$ & $\begin{array}{c}21 \\
0.73\end{array}$ & $\begin{array}{c}45 \\
0.62\end{array}$ \\
\hline \multicolumn{4}{|c|}{ 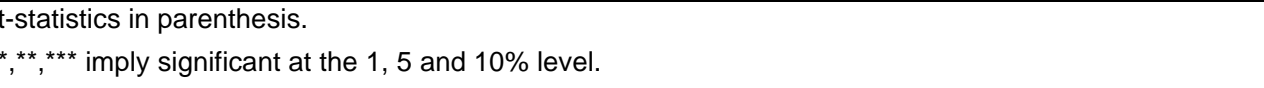 } \\
\hline \multicolumn{4}{|c|}{ Non Agr. Exp/GNP. Distribution in sub-sample } \\
\hline Sample Mean & .0377 & .0180 & .0470 \\
\hline Std. Dev. & .0688 & .0195 & .0810 \\
\hline Min. & .0000 & .0015 & .0000 \\
\hline Max. & .3654 & .0590 & .3654 \\
\hline
\end{tabular}

In Table 13, we present the results from the cross-section and a panel before the fixed effects. We also included in the table a variable that measures ethno-linguistic fractionalization. This comes from La Porta et al. [5]. ${ }^{18}$ The idea is to introduce a variable that represents an "exogenous" institutional setting, since it is argue that rents coming from the resource sector might have an impact on the institutional setting.

${ }^{18}$ See Appendix D. 
Table 13: Resource Abundance and Institutions

\begin{tabular}{|c|c|c|c|c|c|c|}
\hline \multicolumn{7}{|c|}{$\begin{array}{c}\text { Dependent Variable: Average Annual GDP Growth Rate } \\
\text { for Non-Resource Growth }\end{array}$} \\
\hline & \multicolumn{3}{|c|}{ Cross-Section } & \multicolumn{3}{|c|}{ Panel (Pooled) } \\
\hline & $(1.1)$ & '(1.2) & (1.3) & $(2.1)$ & '(2.2) & (2.3) \\
\hline Non-Agr./GNP & $\begin{array}{l}-.1222^{*} \\
(-4.862)\end{array}$ & $\begin{array}{l}-.1070^{*} \\
(-4.090)\end{array}$ & $\begin{array}{l}-.1040^{*} \\
(-3.876)\end{array}$ & $\begin{array}{l}-.0381^{\star *} \\
(-1.899)\end{array}$ & $\begin{array}{l}-.0329^{* * *} \\
(-1.644)\end{array}$ & $\begin{array}{l}-.0220 \\
(-1.074)\end{array}$ \\
\hline Agricultural/GNP & $\begin{array}{l}-.0470^{* * *} \\
(-1.903)\end{array}$ & $\begin{array}{l}-.0519^{* *} \\
(-2.132)\end{array}$ & $\begin{array}{l}-.0531^{* *} \\
(-2.157)\end{array}$ & $\begin{array}{l}-.0461 \\
(-1.351)\end{array}$ & $\begin{array}{l}-.0537 \\
(-1.580)\end{array}$ & $\begin{array}{c}-.0509 \\
(-1.523)\end{array}$ \\
\hline Bureaucracy & & $\begin{array}{l}-.0023^{\star \star \star} \\
(-1.730)\end{array}$ & $\begin{array}{l}-.0025^{\star \star \star} \\
(-1.789)\end{array}$ & & $\begin{array}{c}-.0032^{* \star \star} \\
(-1.782)\end{array}$ & $\begin{array}{l}-.0035^{\star *} \\
(-1.981)\end{array}$ \\
\hline Fractionalization & & & $\begin{array}{l}-.0037 \\
(-0.576)\end{array}$ & & & $\begin{array}{l}-.0173^{* *} \\
(-1.994)\end{array}$ \\
\hline \multicolumn{7}{|l|}{ Bur.Non-Agr.Exp. } \\
\hline \multicolumn{7}{|l|}{ Bur.Agr.Exp. } \\
\hline Log.GDP & $\begin{array}{l}-.0106^{\star} \\
(-4.449)\end{array}$ & $\begin{array}{l}-.0130^{\star} \\
(-4.795)\end{array}$ & $\begin{array}{l}-.0139^{\star} \\
(-4.363)\end{array}$ & $\begin{array}{l}-.0141^{*} \\
(-4.519)\end{array}$ & $\begin{array}{l}-.0177^{*} \\
(-4.809)\end{array}$ & $\begin{array}{l}-.0219^{*} \\
(-5.235)\end{array}$ \\
\hline$\%$ Years & $\begin{array}{l}.0213^{*} \\
(4.531)\end{array}$ & $\begin{array}{l}.0172^{*} \\
(3.337)\end{array}$ & $\begin{array}{l}.0175^{*} \\
(3.351)\end{array}$ & $\begin{array}{l}.0247^{\star} \\
(4.471)\end{array}$ & $\begin{array}{l}.0197^{\star} \\
(3.207)\end{array}$ & $\begin{array}{c}.0210^{*} \\
(3.459)\end{array}$ \\
\hline Log Inv./GDP & $\begin{array}{l}.0085^{\star \star \star} \\
(1.952)\end{array}$ & $\begin{array}{c}.0066 \\
(1.500)\end{array}$ & $\begin{array}{c}.0064 \\
(1.430)\end{array}$ & $\begin{array}{l}.0092^{\star \star \star} \\
(1.776)\end{array}$ & $\begin{array}{c}.0070 \\
(1.334)\end{array}$ & $\begin{array}{c}.0069 \\
(1.326)\end{array}$ \\
\hline Obs & 53 & 53 & 53 & 94 & 94 & 94 \\
\hline $\mathrm{N}$ & & & & 47 & 47 & 47 \\
\hline $\mathrm{T}$ & & & & 2 & 2 & 2 \\
\hline
\end{tabular}

t-statistics in parenthesis.

${ }^{*},{ }^{* * * *}$ imply significant at the 1,5 and $10 \%$ level.

In the table, we see that the effect of the primary exports disappears once institutional variables are introduced in the panel, while it remains significant in the cross-section. The difference between those regressions is that in the panel we allow for the fluctuations of the primary exports over time, while in the cross-section primary exports are only going to divide the sample into resource-rich and resource-poor countries. Therefore, the cross-section indicates that there exists a difference between countries driven by their resource abundance.

\section{Credit Contraints and Debt Overhang}

The previous exercises indicate that neither the classification of countries into developed and developing countries, nor the introduction of institutions change the basic result that the negative 
effect is present on the cross-section. In this sub-section, we present evidence that the results on the "curse" are mainly due to credit constraint considerations.

Giving a further look to Figure 4 indicates that the countries that are driving the result has gone either trough an International Monetary Fund and/or a World Bank Program (including Debt Relieves). This is confirmed by Figure 5.

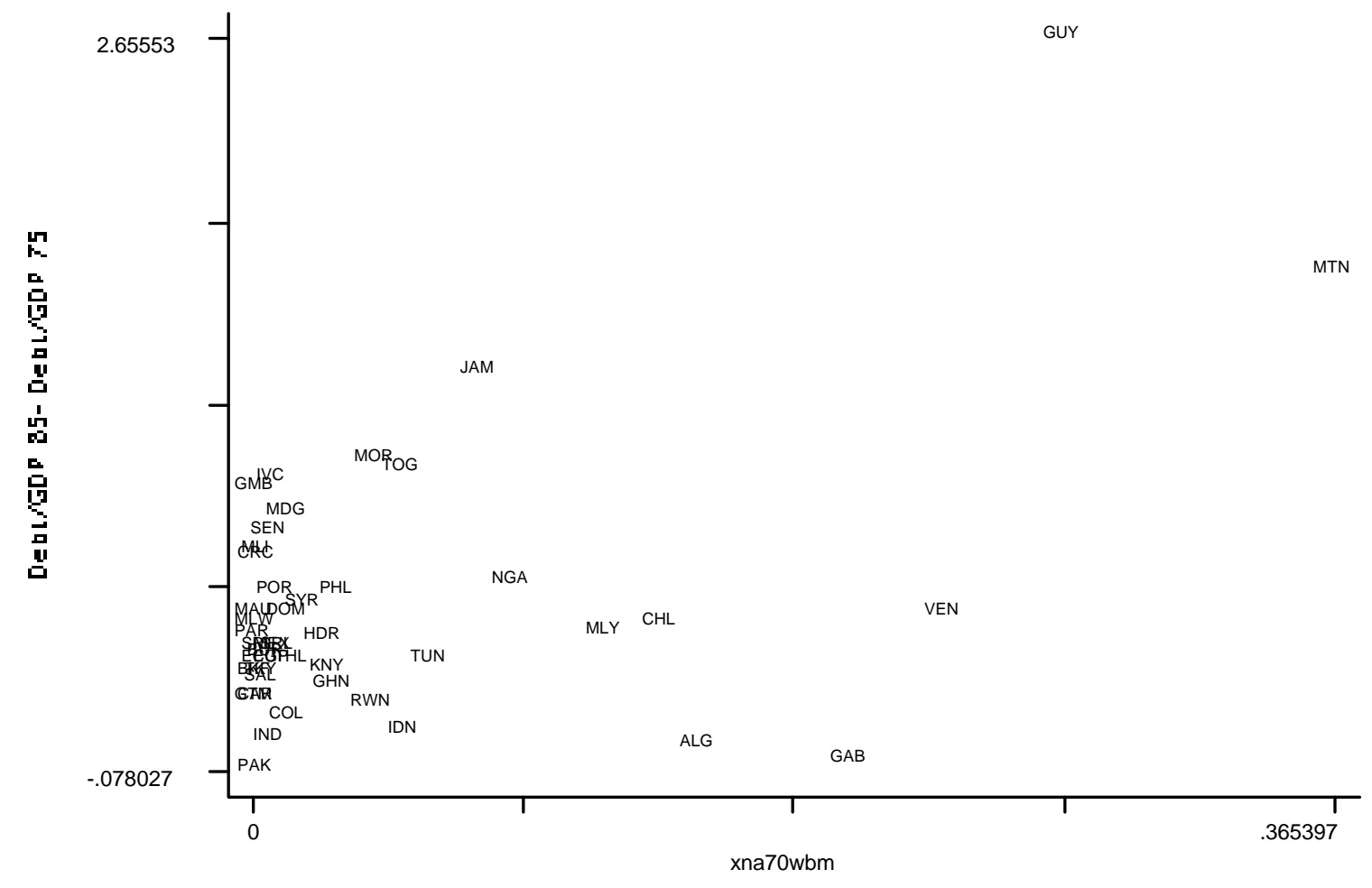

Figure 5: Debt Growth and Resource Abundance

The previous regressions were done using the period 1970-1990. As seen in Figure 6, during the 70's, commodity prices were high and might have induced resource abundant countries to use them as collateral. Then, the 80's saw a fall in commodity prices leading to a debt crisis, which most of these countries faced.

Figure 6 shows the evolution of commodity prices of Coal, Copper, Iron and Oil. The prices are the nominal prices, where (for comparison reasons) they have been normalized to be equal to 
100 in 1970. As can be seen, during the mid-70's the increases in commodity prices were quite dramatic. However, all experienced drops as large as 30 percent during the 80 's.

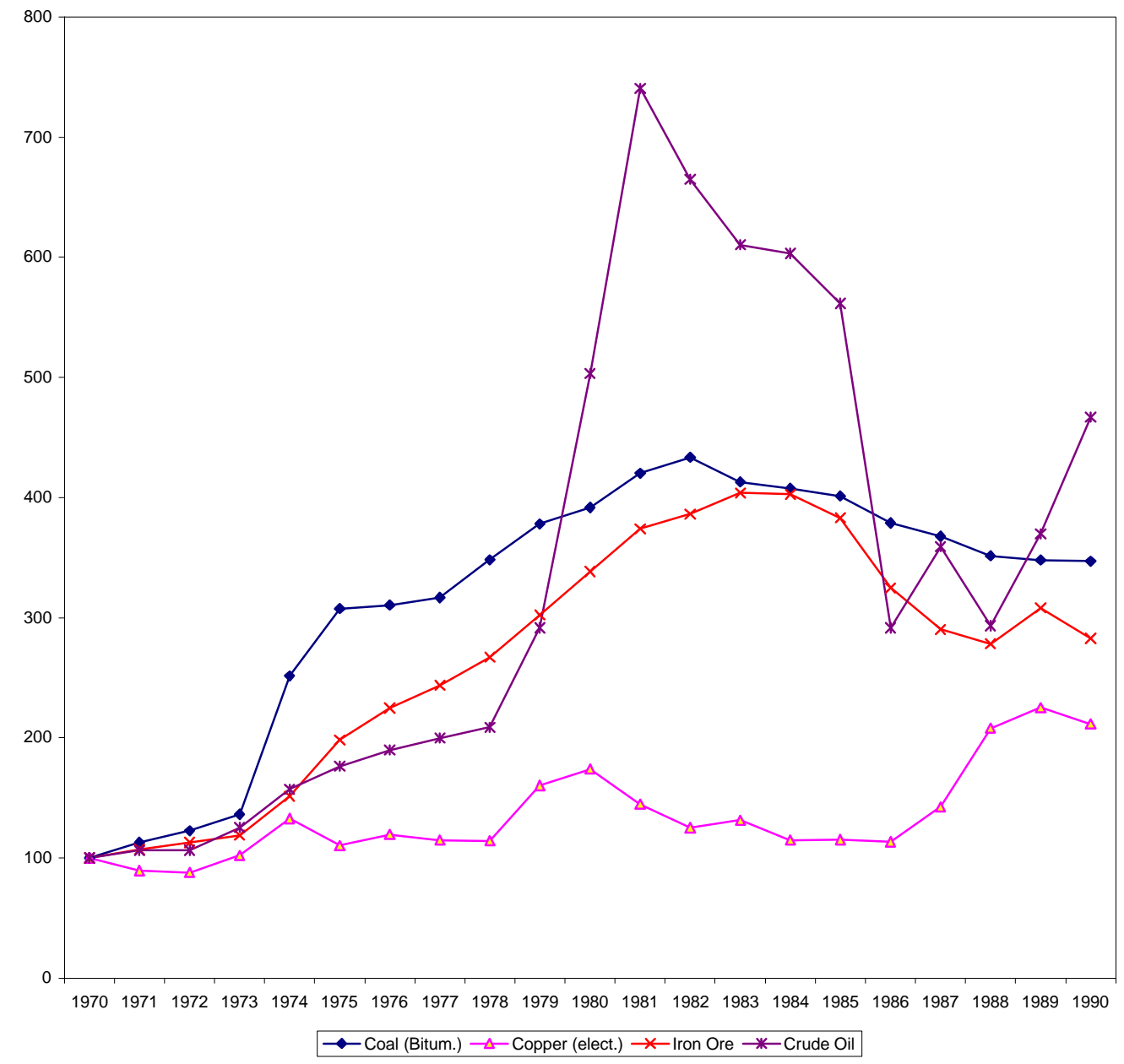

Figure 6: Commodity Prices

In Table 14, we present the change in the prices every five years. Note between 1970-1975 coal, natural gas, and iron experienced price increases that doubled their prices. Moreover, in 19751980 oil and natural gas experienced their own "boom". Coal is perhaps the most stable price in this sample, but still its priced increase by 60 percent in the last five years of the decade of the 70's.

During the first 5 years of the 80's, coal, natural gas, iron and oil experienced an important slowdown in their price increases to finish the decade with falls. Copper is the only exception who suffered the fall in prices at the beginning and then a recovery. 
Table 14: Price growth rate every 5 years.

\begin{tabular}{cccccc}
\hline \hline & $\begin{array}{c}\text { Coal } \\
\text { (Bitum.) }\end{array}$ & Nat. Gas & $\begin{array}{c}\text { Copper } \\
\text { (elect.) }\end{array}$ & Iron Ore & Crude Oil \\
\cline { 2 - 6 } $1970-75$ & $207.6 \%$ & $163.2 \%$ & $10.3 \%$ & $98.2 \%$ & $76.2 \%$ \\
$1975-80$ & $27.3 \%$ & $253.3 \%$ & $57.8 \%$ & $70.8 \%$ & $185.6 \%$ \\
$1980-85$ & $2.4 \%$ & $57.9 \%$ & $-33.9 \%$ & $13.2 \%$ & $11.6 \%$ \\
$1985-90$ & $-13.5 \%$ & $-31.9 \%$ & $83.6 \%$ & $-26.2 \%$ & $-16.9 \%$ \\
\hline \hline
\end{tabular}

If investment and debt decisions in the late 70's were based on the recent estimated price increases, then it should become clear that during the first slow down in the early 80's the countries had problems rolling over their debts. This motivates the regressions found in Table 15.

In the table, we divide the sample in two periods: 1970-1980 and 1980-1990. From the table, it is clear that the share of non-agricultural exports at the beginning of the period did not have an effect on growth from 1970 to 1980 . Nevertheless, they have a negative from 1980 to 1990. However, in column (3) we changed it to the share of non-agricultural exports in 1970 . We see that the coefficient is higher ${ }^{19}$ and the significance of the regression is higher.

We go a step further and construct a variable called credit constraint, which is the Debt/GNP ratio in 1981 for less developed countries (LDC's) and zero (0) for developed countries. We then repeat the regression done in column (3) including this variable. The result shows that non-agricultural exports no longer have a negative effect and rather this credit constraint ratio have a negative effect on growth. This implies that the resource abundance variable was picking the fact that these countries were highly indebted at the beginning of the decade ${ }^{20}$.

\footnotetext{
${ }^{19}$ The p-value for a t-test that they are different is 0.083 .

${ }^{20}$ In Appendix E, we also test jointly this explanation with alternative explanations to the "curse". The results confirm the results find here.
} 
Table 15: Natural Resources and Credit Constraints

\begin{tabular}{|c|c|c|c|c|}
\hline \multicolumn{5}{|c|}{ Dependent Variable: Average Annual GDP Growth Rate } \\
\hline \multirow{4}{*}{ Non-Agr. Exp./GNP 1970} & \multirow{2}{*}{$\frac{\text { Period: } 1970-1980}{(1)}$} & \multicolumn{3}{|c|}{ Period: $1980-1990$} \\
\hline & & $(2)$ & (3) & (4) \\
\hline & -.0525 & & $-.1385^{\star}$ & -.0314 \\
\hline & $(-1.256)$ & & $(-3.385)$ & $(-1.452)$ \\
\hline Non-Agr. Exp./GNP 1980 & & $\begin{array}{l}-.0571^{*} \\
(-2.683)\end{array}$ & & \\
\hline Credit Constraint (1981) & & & & $\begin{array}{l}-.0524^{*} \\
(-2.954)\end{array}$ \\
\hline Log. GDP (Beginning of Period) & $\begin{array}{l}-.0091^{* *} \\
(-2.199)\end{array}$ & $\begin{array}{l}-.0159^{*} \\
(-3.988)\end{array}$ & $\begin{array}{l}-.0171^{*} \\
(-4.396)\end{array}$ & $\begin{array}{l}-.0206^{\star} \\
(-5.087)\end{array}$ \\
\hline$\%$ Years Open & $\begin{array}{l}.0233^{*} \\
(3.166)\end{array}$ & $\begin{array}{l}.0230^{\star *} \\
(2.500)\end{array}$ & $\begin{array}{l}.0258^{\star} \\
(2.988)\end{array}$ & $\begin{array}{l}.0205^{\star \star} \\
(2.376)\end{array}$ \\
\hline Log.Invest./GDP (Average of the Period) & $\begin{array}{c}.0077 \\
(1.540)\end{array}$ & $\begin{array}{l}.0189^{\star} \\
(3.700)\end{array}$ & $\begin{array}{l}.0199^{\star} \\
(4.015)\end{array}$ & $\begin{array}{l}.0205^{\star} \\
(4.279)\end{array}$ \\
\hline Agr. Exp./GNP & $\begin{array}{l}.0674^{* * *} \\
(1.746)\end{array}$ & $\begin{array}{l}-.0366 \\
(-0.790)\end{array}$ & $\begin{array}{l}-.0421 \\
(-0.943)\end{array}$ & $\begin{array}{l}-.0303 \\
(-0.701)\end{array}$ \\
\hline $\begin{array}{c}\mathrm{N} \\
\text { Adj. } \mathrm{R}^{2}\end{array}$ & $\begin{array}{c}58 \\
0.23\end{array}$ & $\begin{array}{c}58 \\
0.37\end{array}$ & $\begin{array}{c}58 \\
0.42\end{array}$ & $\begin{array}{c}58 \\
0.45\end{array}$ \\
\hline
\end{tabular}

t-statistics in parenthesis.

${ }^{*},{ }^{* *}{ }^{* * *}$ imply significant at the 1,5 and $10 \%$ level.

\section{Conclusions}

This paper considers several reasons behind the perceived poor performance of resourceintensive economies. It reestimates the effect of natural resource abundance on growth using panel data and improved measures of the non-resource side of the economy. We found that the effect is always present in the cross-section data and not in the panel data. We argue that the empirical finding in the cross sectional is due to omitted variable biases.

We thoroughly examine the possible candidates to explain the cross sectional results. We found that degree of development and the quality of institutions were important determinants of the growth, however, they were not the cause of the "curse" 
On the other hand, we show that it is due to the fact that these countries decided to take advantage of high commodity prices on the 70's to use them as implicit collateral and found themselves on a debt overhang when commodity prices fell in the 80's.

Therefore, rather than a problem associated with the presence of natural resources, these result seems to point out to credit market imperfections as reason for bad performance. If we think of the commodity production of a country as part of their collateral, an increase in prices relaxes the degree of credit constraint allowing those governments to increase their foreign debts. During the slow down in prices and the subsequent fall, the countries were unable to continue to borrow and had to repay part of their debts. In the end, devaluations and other contractionary measures had to be taken to balance the current accounts, with their usual toll on growth.

Our reading of the evidence is that the curse of natural resources is not due to the particular aspect of excessively depending on natural resources what slows down the growth rates. It is the interaction between credit markets and a collateralizable good that is experiencing a bubble, what causes the problems in the end. In this respect, a boom-bust cycle in a commodity price is no different from a bubble in stock markets, as was the case of Japan, or a bubble in real estate prices, as was in New England and Thailand.

Our interpretation is that the curse of natural resources, in this data, is another example of the curse on asset prices bubbles. Future research should continue to explore the interaction of credit market imperfections and the determinants of the growth. Finally, extending the present analysis beyond the early 90's might help to unveil the relative importance of debt overhang issues from other curses.

\section{Appendix}

\section{A. Sample Selection}

In their paper, Sachs and Warner change the base year for which the share of primary exports is computed for 16 countries. The reasons behind those changes range from including more countries in the sample, to including primary exports missing in National Accounts, to excluding "refinery countries" (countries that export fuels because they import fuels to refine). As we argue in section 
2, the problem that arises from those changes is that, the correct regression would be a panel. Therefore, we will always need "beginning of period measures" of the share of primary exports.

In Table 16 we show the steps we take to solve this problem.

Table 16: Sample Selection

\begin{tabular}{|c|c|c|c|c|c|c|}
\hline \multicolumn{7}{|c|}{ Dependent Variable: Average Annual GDP Growth Rate } \\
\hline & \multirow{4}{*}{$\begin{array}{c}\text { Sachs and } \\
\text { Warner }\end{array}$} & \multicolumn{5}{|c|}{ This Sample } \\
\hline & & \multicolumn{3}{|c|}{ With Modified Countries } & \multirow{2}{*}{\multicolumn{2}{|c|}{$\begin{array}{c}\text { Without } \\
\text { Modified } \\
\text { Countries }\end{array}$}} \\
\hline & & $\begin{array}{c}\text { Full } \\
\text { Sample }\end{array}$ & $\begin{array}{l}\text { Prim. } \\
\text { can be }\end{array}$ & $\begin{array}{l}\text { /GDP } \\
\text { culated }\end{array}$ & & \\
\hline & & $(2.1)$ & (2.2) & (2.3) & (3.1) & (3.2) \\
\hline Log. GDP 70 & $\begin{array}{c}-.0134 \\
(-7.77)\end{array}$ & $\begin{array}{l}-.0127 \\
(-7.021)\end{array}$ & $\begin{array}{l}-.0134 \\
(-6.996)\end{array}$ & $\begin{array}{l}-.0121 \\
(-5.581)\end{array}$ & $\begin{array}{l}-.0135 \\
(-6.697)\end{array}$ & $\begin{array}{l}-.0135 \\
(-6.698)\end{array}$ \\
\hline $\begin{array}{l}\text { Prim. Exp./GNP } 70 \\
\text { (Sachs and Warner) }\end{array}$ & $\begin{array}{l}-.0729 \\
(-0.242)\end{array}$ & $\begin{array}{l}-.0584 \\
(-5.029)\end{array}$ & $\begin{array}{c}-.0722 \\
(-5.894)\end{array}$ & & $\begin{array}{l}-.0700 \\
(-5.666)\end{array}$ & \\
\hline $\begin{array}{l}\text { Prim. Exp./GNP } 70 \\
\text { (This Sample) }\end{array}$ & & & & $\begin{array}{l}-.0344 \\
(-2.970)\end{array}$ & & $\begin{array}{l}-.0700 \\
(-5.667)\end{array}$ \\
\hline Years Open 70-89 & $\begin{array}{l}.0242 \\
(7.06)\end{array}$ & $\begin{array}{c}.0260 \\
(7.403)\end{array}$ & $\begin{array}{c}.0232 \\
(6.234)\end{array}$ & $\begin{array}{c}.0257 \\
(6.074)\end{array}$ & $\begin{array}{l}0.0235 \\
(6.028)\end{array}$ & $\begin{array}{l}0.0235 \\
(6.028)\end{array}$ \\
\hline Log. Investment/GDP 70-89 & $\begin{array}{l}.0102 \\
(5.63) \\
\end{array}$ & $\begin{array}{l}.0133 \\
(6.018) \\
\end{array}$ & $\begin{array}{l}.0144 \\
(5.768) \\
\end{array}$ & $\begin{array}{c}.0131 \\
(4.616) \\
\end{array}$ & $\begin{array}{l}0.0140 \\
(5.539) \\
\end{array}$ & $\begin{array}{l}0.0140 \\
(5.540)\end{array}$ \\
\hline $\begin{array}{c}\mathrm{N} \\
\text { Adj. } \mathrm{R}^{2}\end{array}$ & $\begin{array}{c}87 \\
0.67\end{array}$ & $\begin{array}{c}95 \\
0.64\end{array}$ & $\begin{array}{c}82 \\
0.66\end{array}$ & $\begin{array}{c}82 \\
0.54\end{array}$ & $\begin{array}{c}78 \\
0.64\end{array}$ & $\begin{array}{c}79 \\
0.65\end{array}$ \\
\hline
\end{tabular}

t-statistics in parenthesis.

All coefficents are significant at any level

First, in column (1.1) we have the results reported by Sachs and Warner. Then, column (2.1) uses my entire sample, but the share of primary exports, which is taken directly from Sachs and Warner [8]. As can be seen the coefficients are not significantly different from (1.1). The same regression is then repeated in column (2.2), but only for those countries for which we would be able to compute the share of primary exports. Again, the coefficients are not significantly different to those in (1.1). The next step is to do the same regression but now using my computed share of primary exports. We see that the coefficient in the share of primary exports changes substantially. This may be due to the presence of those countries for which Sachs and Warner changed the share of primary exports. Therefore, in columns (3.1) and (3.2) we repeated regressions (2.2) and (2.3), respectively, without the countries that Sachs and Warner modified. It is clear that the coefficients in (2.1) and (3.2) are not significantly different nor are they significantly different from the original Sachs and Warner results in (1.1). For that reason we are going to use this group of countries. 


\section{B. Change in Primary Exports}

Figures I and II compare the share of primary exports and "real" primary exports to GNP in 1970 and 1980. They illustrate that there are important changes in the shares. They also illustrate, that those changes are not only among the biggest primary exporters.

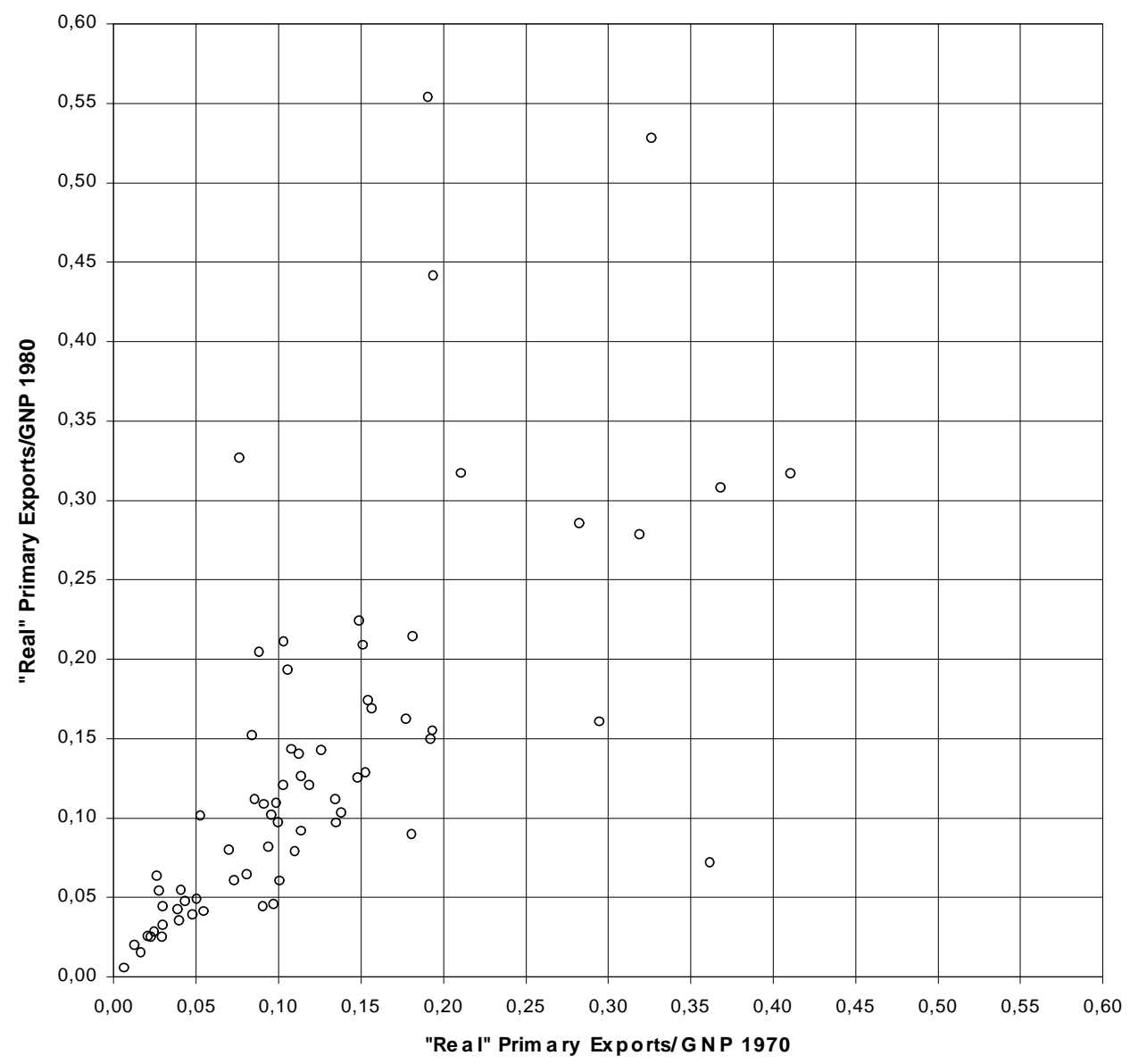

Figure I:Change in "Real" Share of Exports 


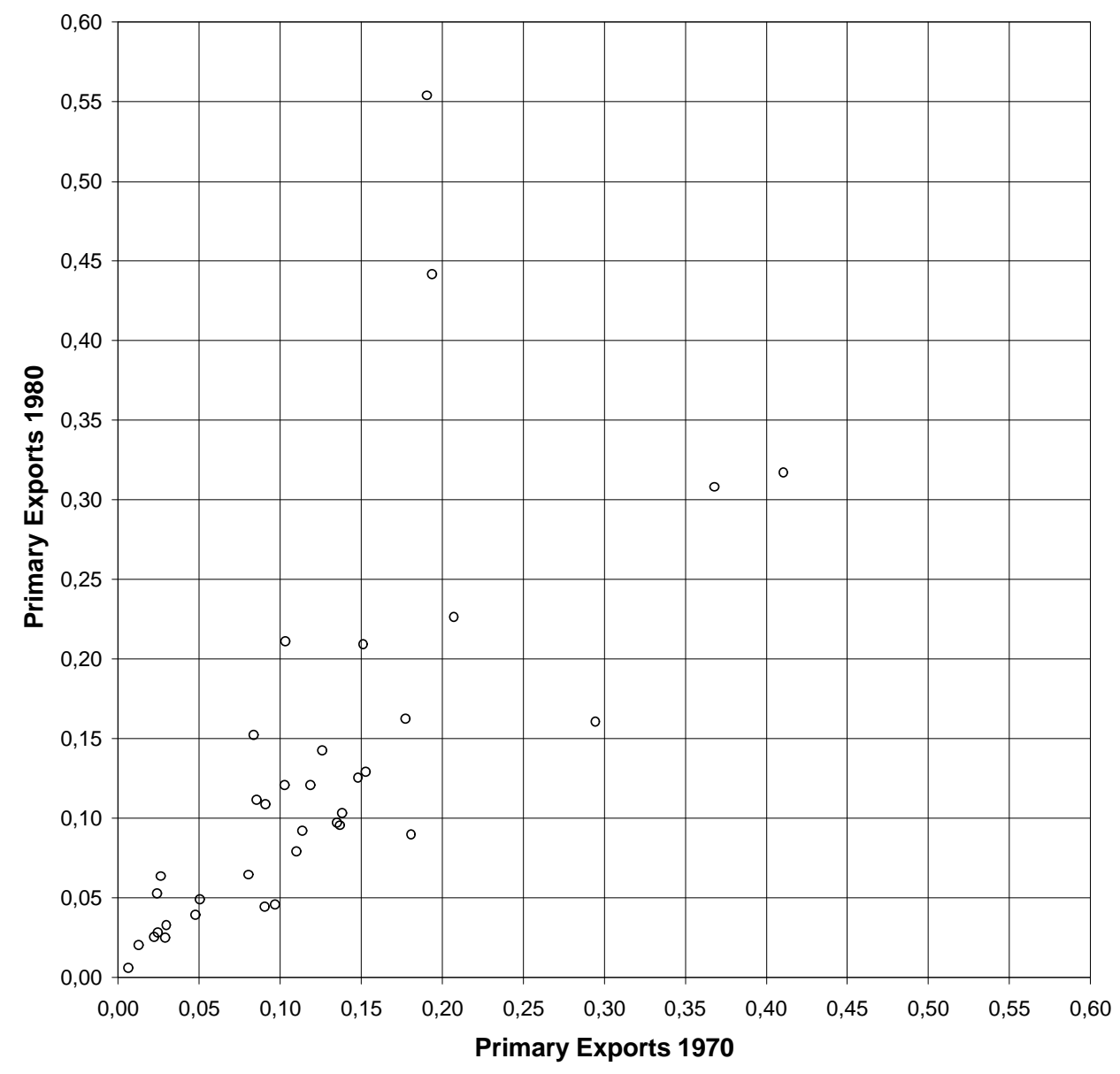

Figure II: Change in the Share of Exports

\section{Alternative measure of Non-Resource GDP.}

The World Bank provides data on some sectors of countries' economies, in particular manufacturing and services. In this subsection we estimate the effect of resource exports on the combined GDP --as a proxy for the non-resource sector.

In Table 17, we present the results from a cross-section of countries. From the result for the total GDP, we see that the result from Sachs and Warner is present in this regression. In the 
sectorial data, we find that we still get a negative effect from primary exports. ${ }^{21}$ This seems to suggest that there is the predicted negative effect.

Table 17: Manufacturing and Services GDP

\begin{tabular}{lcc}
\hline \hline \multicolumn{3}{c}{ Dependent Variable: Average Annual GDP Growth Rate } \\
\hline & $\begin{array}{c}\text { Using } \\
\text { Total GDP }\end{array}$ & $\begin{array}{c}\text { Using } \\
\text { Non-Resource GDP }\end{array}$ \\
\cline { 2 - 3 } Prim. Exp./GNP & -.0604 & -.0659 \\
& $(-4.790)$ & $(-2.744)$ \\
Log. GDP 70 & -.0157 & -.0108 \\
& $(-7.061)$ & $(-2.418)$ \\
Years Open 70-90 & .0302 & .0316 \\
& $(6.781)$ & $(3.363)$ \\
Log. Invest./GDP 70-89 & .0143 & .0131 \\
& $(4.967)$ & $(2.239)$ \\
\hline \multicolumn{1}{c}{${ }^{2}$} & 54 & 54 \\
$\mathrm{R}^{2}$ & 0.72 & 0.35 \\
\hline \hline t-statistics in parenthesis. & & \\
All coefficents are significant at any level &
\end{tabular}

In Table 18, we proceed to reestimate the effect with a panel. It indicates that once a panel with fixed effects is done, the negative effect of primary exports is lost. Consequently, it seems that there is no evidence of a negative effect from resource abundance in the growth of non-resource sectors.

\footnotetext{
${ }^{21}$ This result is also found by Sachs and Warner [8] in their paper. See Table VIII, column (8.2). However, in Manzano [6], the sectors are divided looking for evidence of "Dutch Diesease" and it is found that the negative effect is found on the service sector and not in the manufacturing sector, contrary to what it is expected from the "Dutch Disease" literature.
} 
Table 18: Manufacturing and Service GDP: Cross-Section vs. Panel

\begin{tabular}{lccc}
\hline \hline \multicolumn{3}{c}{ Dependent Variable: Average Annual GDP Growth Rate } \\
\hline & Cross-Sctn & Pooled & Panel \\
\cline { 2 - 4 } Prim. Exp./GNP & $-.0780^{*}$ & $-.0430^{\star *}$ & $.0882^{\star \star \star}$ \\
& $(-2.860)$ & $(-1.958)$ & $(1.815)$ \\
Log. GDP 70 & & & \\
& $-.0080^{\star * *}$ & $-.0152^{\star}$ & $-.0619^{\star}$ \\
\%Years Open 70-90 & $(-1.835)$ & $(-4.160)$ & $(-5.412)$ \\
& $.0309^{*}$ & $.0290^{*}$ & -.0146 \\
Log. Invest./GDP 70-89 & $(3.261)$ & $(3.819)$ & $(-0.886)$ \\
& .0001 & .0101 & -.0076 \\
Hausman Test & $(0.195)$ & $(1.439)$ & $(-0.483)$ \\
F Test all ui=0 & & & 50.02 \\
Obs & & & 2.27 \\
$\mathrm{~N}$ & 48 & 96 & 96 \\
$\mathrm{~T}$ & & 48 & 48 \\
\hline \hline
\end{tabular}

t-statistics in parenthesis.

${ }^{*},{ }^{* *},{ }^{* *}$ imply significant at the 1,5 and $10 \%$ level.

\section{Alternative Institutional Variables}

In Table 19, we repeat the estimation done in the cross-sections of Table 13, with other institutional variables. These variables represent a corruption index, a rule of law index, an index that tries to capture the risk of government repudiation, and another the tries to capture the expropriation risk. $^{22}$ It is clear that these variables are not statistically significant, while the nonagricultural resource abundance variable continues to be significant in the regression.

${ }^{22}$ See Appendix E for a complete description of the variables. 
Table 19: Alternative Institutional Variables

\begin{tabular}{|c|c|c|c|c|c|c|c|c|}
\hline \multicolumn{9}{|c|}{$\begin{array}{l}\text { Dependent Variable: Average Annual GDP Growth Rate } \\
\text { for Non-Resource Growth. }\end{array}$} \\
\hline & \multicolumn{8}{|c|}{ Cross-Section } \\
\hline & $(1.1)$ & $(1.2)$ & $(2.1)$ & $(2.2)$ & (3.1) & $(3.2)$ & $(4.1)$ & $(4.2)$ \\
\hline Non-Agr./GNP & $\begin{array}{l}-.1129^{*} \\
(-3.483)\end{array}$ & $\begin{array}{l}-.1110^{*} \\
(-3.171)\end{array}$ & $\begin{array}{l}-.1079^{*} \\
(-3.307)\end{array}$ & $\begin{array}{l}-.1053^{\star} \\
(-2.949)\end{array}$ & $\begin{array}{l}-.1242^{*} \\
(-3.782)\end{array}$ & $\begin{array}{l}-.1246^{*} \\
(-3.436)\end{array}$ & $\begin{array}{l}-.1275^{\star} \\
(-3.925)\end{array}$ & $\begin{array}{l}-.1282^{*} \\
(-3.546)\end{array}$ \\
\hline Corruption & $\begin{array}{c}.0011 \\
(0.7089)\end{array}$ & $\begin{array}{c}.0012 \\
(0.7709)\end{array}$ & & & & & & \\
\hline Rule of Law & & & $\begin{array}{c}.0025 \\
(-1.424)\end{array}$ & $\begin{array}{c}.0026 \\
(1.417)\end{array}$ & & & & \\
\hline Gov. Repudiation & & & & & $\begin{array}{l}0.0015 \\
(0.903)\end{array}$ & $\begin{array}{l}.0015 \\
(.8944)\end{array}$ & & \\
\hline Exp. Risk & & & & & & & $\begin{array}{l}.0007 \\
(.4501)\end{array}$ & $\begin{array}{l}.0007 \\
(.4340)\end{array}$ \\
\hline Fractionalization & & $\begin{array}{c}-.0027 \\
(-0.362)\end{array}$ & & $\begin{array}{c}-.0034 \\
(-0.471)\end{array}$ & & $\begin{array}{l}.0004 \\
(.0396)\end{array}$ & & $\begin{array}{l}.0007 \\
(.0710)\end{array}$ \\
\hline Log.GDP & $\begin{array}{l}-.0118^{\star} \\
(-3.887)\end{array}$ & $\begin{array}{l}-.0124^{\star} \\
(-3.579)\end{array}$ & $\begin{array}{l}-.0135^{\star} \\
(-3.887)\end{array}$ & $\begin{array}{l}-.0144^{\star} \\
(-3.665)\end{array}$ & $\begin{array}{c}-.0089^{\star} \\
(-2.934)\end{array}$ & $\begin{array}{c}-.0087^{\star \star \star} \\
(-1.766)\end{array}$ & $\begin{array}{c}-.0090^{\star} \\
(-2.883)\end{array}$ & $\begin{array}{c}-.0087 \\
(-1.711)\end{array}$ \\
\hline$\%$ Years & $\begin{array}{l}.0195^{*} \\
(3.866)\end{array}$ & $\begin{array}{l}.0197^{*} \\
(3.838)\end{array}$ & $\begin{array}{l}0.0178^{\star} \\
(3.645)\end{array}$ & $\begin{array}{l}.0181^{*} \\
(3.622)\end{array}$ & $\begin{array}{l}.0198^{*} \\
(3.078)\end{array}$ & $\begin{array}{l}.0198^{*} \\
(3.039)\end{array}$ & $\begin{array}{l}.0215^{\star} \\
(3.433)\end{array}$ & $\begin{array}{c}.0215 \\
(3.384)\end{array}$ \\
\hline Log Inv./GDP & $\begin{array}{c}.0074 \\
(1.602)\end{array}$ & $\begin{array}{c}.0072 \\
(1.524)\end{array}$ & $\begin{array}{c}.0058 \\
(-1.139)\end{array}$ & $\begin{array}{c}.0056 \\
(1.059)\end{array}$ & $\begin{array}{l}.0075 \\
1.350\end{array}$ & $\begin{array}{c}.0075 \\
(1.2717)\end{array}$ & $\begin{array}{c}.0074 \\
(1.319)\end{array}$ & $\begin{array}{c}.0075 \\
(1.220)\end{array}$ \\
\hline Agricultural/GNP & $\begin{array}{c}-.0555 \\
(-1.670)\end{array}$ & $\begin{array}{c}-.0584 \\
(-1.671) \\
\end{array}$ & $\begin{array}{c}-.0491 \\
(-1.546) \\
\end{array}$ & $\begin{array}{c}-.0500 \\
(-1.517)\end{array}$ & $\begin{array}{c}-.0485 \\
(-1.195) \\
\end{array}$ & $\begin{array}{c}-.0482 \\
(-1.092) \\
\end{array}$ & $\begin{array}{c}-.0513 \\
(-1.275)\end{array}$ & $\begin{array}{c}-.0508 \\
(-1.146)\end{array}$ \\
\hline $\begin{array}{c}\mathrm{N} \\
\text { Adj. } \mathrm{R}\end{array}$ & $\begin{array}{c}53 \\
0.57\end{array}$ & $\begin{array}{c}53 \\
0.57\end{array}$ & $\begin{array}{c}53 \\
0.59\end{array}$ & $\begin{array}{c}53 \\
0.58\end{array}$ & $\begin{array}{c}36 \\
0.55\end{array}$ & $\begin{array}{c}36 \\
0.53\end{array}$ & $\begin{array}{c}36 \\
0.54\end{array}$ & $\begin{array}{c}36 \\
0.53\end{array}$ \\
\hline
\end{tabular}

t-statistics in parenthesis.

*,***** imply significant at the 1,5 and $10 \%$ level.

\section{E. Robustness Check.}

In this appendix we test together our reading of the resource "curse" and alternative explanations to it. In Table 20, we present the result of repeating the regressions found on Table 15, but adding institutional performance. The degree of financial development should be correlated with rule of law and the quality of the bureaucracy. In this regression, we test for the robustness in our results regarding the credit constraint results. 
Table 20: Credit Constraints and Institutions

\begin{tabular}{|c|c|c|c|c|}
\hline \multicolumn{5}{|c|}{ Dependent Variable: Average Annual GDP Growth Rate } \\
\hline \multirow{4}{*}{ Non-Agr. Exp./GNP 1970} & \multirow{4}{*}{$\begin{array}{c}\text { Period: } 1970-1980 \\
(1) \\
-.1032^{\star \star} \\
(-1.827)\end{array}$} & \multicolumn{3}{|c|}{ Period: $1980-1990$} \\
\hline & & $(2)$ & (3) & (4) \\
\hline & & & $-.0848^{* * *}$ & -.0537 \\
\hline & & & $(-1.842)$ & $(-1.144)$ \\
\hline Non-Agr. Exp./GNP 1980 & & $\begin{array}{l}-.0430^{\star *} \\
(-2.090)\end{array}$ & & \\
\hline Credit Constraint (1981) & & & & $\begin{array}{l}-.0405^{\star *} \\
(-2.027)\end{array}$ \\
\hline Bureaucracy & $\begin{array}{c}.0024 \\
(0.893)\end{array}$ & $\begin{array}{c}.0029 \\
(1.272)\end{array}$ & $\begin{array}{l}.0032 \mathrm{c} \\
(1.403)\end{array}$ & $\begin{array}{c}.0024 \\
(1.097)\end{array}$ \\
\hline Log. GDP (Beginning of Period) & $\begin{array}{c}-.0095^{\star * *} \\
(-1.733)\end{array}$ & $\begin{array}{l}-.0243^{*} \\
(-5.434)\end{array}$ & $\begin{array}{l}-.0233^{*} \\
(-5.151)\end{array}$ & $\begin{array}{l}-.0269^{*} \\
(-5.717)\end{array}$ \\
\hline \%Years Open & $\begin{array}{l}.0204^{* *} \\
(2.198)\end{array}$ & $\begin{array}{l}.0197^{\star \star} \\
(2.358)\end{array}$ & $\begin{array}{l}.0202^{* \star} \\
(2.398)\end{array}$ & $\begin{array}{l}.0190^{\star \star} \\
(2.338)\end{array}$ \\
\hline Log.Invest./GDP (Average of the Period) & $\begin{array}{c}.0022 \\
(0.262)\end{array}$ & $\begin{array}{c}.0144 \\
(2.134)\end{array}$ & $\begin{array}{c}.0127^{\star \star *} \\
(1.916)\end{array}$ & $\begin{array}{l}.0149^{\star \star} \\
(2.298)\end{array}$ \\
\hline Agr. Exp./GNP & $\begin{array}{c}.0368 \\
(0.721) \\
\end{array}$ & $\begin{array}{l}-.1161^{*} \\
(-2.777)\end{array}$ & $\begin{array}{l}-.1062^{* *} \\
(-2.554)\end{array}$ & $\begin{array}{l}-.0958^{\star *} \\
(-2.373)\end{array}$ \\
\hline $\begin{array}{c}\mathrm{N} \\
\text { Adj. } \mathrm{R}^{2}\end{array}$ & $\begin{array}{c}47 \\
0.25\end{array}$ & $\begin{array}{c}47 \\
0.44\end{array}$ & $\begin{array}{c}47 \\
0.43\end{array}$ & $\begin{array}{c}47 \\
0.47\end{array}$ \\
\hline
\end{tabular}

t-statistics in parenthesis.

${ }^{*},{ }^{* * *}$ imply significant at the 1,5 and $10 \%$ level.

As can be seen, the resource curse survives the inclusion of bureaucracy. The same conclusion as before is found: The effect of primary exports disappears when credit constraint variables are included in the regression.

A second robustness check is to find how sensitive the results are to other variables that explain growth. In particular, resource abundance could be negatively correlated with many different variables that are used to explain growth ${ }^{23}$. In table 21, we test for one of them, Education. Which, indeed, it is negatively correlated with resource abundance. As seen in the Table the results from Table 15 do not change with the introduction of it.

${ }^{23}$ We thank Bill Easterly for pointing us this fact. 
Table 21: Credit Constraints and Education

\begin{tabular}{|c|c|c|c|c|}
\hline \multicolumn{5}{|c|}{ Dependent Variable: Average Annual GDP Growth Rate } \\
\hline \multirow{4}{*}{ Non-Agr. Exp./GNP 1970} & \multirow{4}{*}{$\begin{array}{c}\text { Period: } 1970-1980 \\
(1) \\
-.0300 \\
(-0.697)\end{array}$} & \multicolumn{3}{|c|}{ Period: $1980-1990$} \\
\hline & & (2) & (3) & (4) \\
\hline & & & $-.1411^{*}$ & -.0720 \\
\hline & & & $(-3.145)$ & $(-1.420)$ \\
\hline Non-Agr. Exp./GNP 1980 & & $\begin{array}{l}-.0786^{\star} \\
(-3.048)\end{array}$ & & \\
\hline Credit Constraint (1981) & & & & $\begin{array}{l}-.0518^{* *} \\
(-2.512)\end{array}$ \\
\hline Sec. Enrollment (Beginning of Per.) & $\begin{array}{l}.0040 \\
(0.861)\end{array}$ & $\begin{array}{c}.0057 \\
(1.076)\end{array}$ & $\begin{array}{c}-.0015 \\
(-0.287)\end{array}$ & $\begin{array}{l}.00357 \\
(0.673)\end{array}$ \\
\hline Log. GDP (Beginning of Period) & $\begin{array}{l}-.0120^{* *} \\
(-2.049)\end{array}$ & $\begin{array}{l}-.0195^{\star} \\
(-3.773)\end{array}$ & $\begin{array}{l}-.0158^{*} \\
(-3.137)\end{array}$ & $\begin{array}{l}-.0226^{*} \\
(-4.115)\end{array}$ \\
\hline \%Years Open & $\begin{array}{l}.0255^{\star} \\
(3.356)\end{array}$ & $\begin{array}{l}.0243^{*} \\
(2.671)\end{array}$ & $\begin{array}{c}.0269^{*} \\
(3.013)\end{array}$ & $\begin{array}{l}.0224^{* *} \\
(2.594)\end{array}$ \\
\hline Log.Invest./GDP (Average of the Period) & $\begin{array}{c}.0059 \\
(1.540)\end{array}$ & $\begin{array}{l}.0147^{\star *} \\
(2.474)\end{array}$ & $\begin{array}{l}.0184^{*} \\
(3.005)\end{array}$ & $\begin{array}{l}.0171^{*} \\
(2.924)\end{array}$ \\
\hline Agr. Exp./GNP & $\begin{array}{c}.0645 \\
(1.653)\end{array}$ & $\begin{array}{c}-.0554 \\
(-1.151)\end{array}$ & $\begin{array}{c}-.0365 \\
(-0.789)\end{array}$ & $\begin{array}{c}-.0360 \\
(-0.820)\end{array}$ \\
\hline $\begin{array}{c}\mathrm{N} \\
\text { Adj. } \mathrm{R}^{2}\end{array}$ & $\begin{array}{c}55 \\
0.35\end{array}$ & $\begin{array}{c}55 \\
0.36\end{array}$ & $\begin{array}{c}55 \\
0.36\end{array}$ & $\begin{array}{c}55 \\
0.43\end{array}$ \\
\hline
\end{tabular}

t-statistics in parenthesis.

${ }^{*},{ }^{* * *}$ imply significant at the 1,5 and $10 \%$ level.

In Table 22 we test for another variable used to explain growth, financial development, measured as M2 to GDP Ratio. It is also negatively correlated with resource abundance. As seen in the Table financial development is indeed significant, and has a positive effect on growth. However, the results from Table 15 still do not change with the introduction of it. This exercise can be repeated with several other variables standard in growth regressions and the results hold. 
Table 22: Credit Constraints and Education

\begin{tabular}{|c|c|c|c|c|}
\hline \multicolumn{5}{|c|}{ Dependent Variable: Average Annual GDP Growth Rate } \\
\hline \multirow{4}{*}{ Non-Agr. Exp./GNP 1970} & Period: $1970-1980$ & \multicolumn{3}{|c|}{ Period: $1980-1990$} \\
\hline & (1) & $(2)$ & (3) & (4) \\
\hline & -.0301 & & $-.1221^{*}$ & -.0694 \\
\hline & $(-0.678)$ & & $(-2.715)$ & $(-1.432)$ \\
\hline Non-Agr. Exp./GNP 1980 & & $-.0472^{\star *}$ & & \\
\hline & & $(-2.046)$ & & \\
\hline Credit Constraint (1981) & & & & $\begin{array}{l}-.0453^{* *} \\
(-2.285)\end{array}$ \\
\hline M2/GDP & $\begin{array}{c}.0202 \\
(0.965)\end{array}$ & $\begin{array}{l}.0425^{\star *} \\
(2.154)\end{array}$ & $\begin{array}{l}.0414^{\star *} \\
(2.182)\end{array}$ & $\begin{array}{l}.0400^{\star *} \\
(2.218)\end{array}$ \\
\hline Log. GDP (Beginning of Period) & $\begin{array}{l}-.0121^{\star *} \\
(-2.490)\end{array}$ & $\begin{array}{l}-.0189^{*} \\
(-4.011)\end{array}$ & $\begin{array}{l}-.0194^{\star} \\
(-4.267)\end{array}$ & $\begin{array}{l}-.0227^{*} \\
(-4.984)\end{array}$ \\
\hline \%Years Open & $\begin{array}{l}.0232^{* *} \\
(2.474)\end{array}$ & $\begin{array}{c}.0133 \\
(1.201)\end{array}$ & $\begin{array}{c}.0141 \\
(1.330)\end{array}$ & $\begin{array}{c}.0115 \\
(1.139)\end{array}$ \\
\hline Log.Invest./GDP (Average of the Period) & $\begin{array}{c}.0067 \\
(1.278)\end{array}$ & $\begin{array}{l}.0191^{\star} \\
(3.446)\end{array}$ & $\begin{array}{l}.0204^{*} \\
(3.781)\end{array}$ & $\begin{array}{l}.0216^{*} \\
(4.206)\end{array}$ \\
\hline Agr. Exp./GNP & $\begin{array}{l}.0867^{\star *} \\
(2.071)\end{array}$ & $\begin{array}{c}.0129 \\
(0.229) \\
\end{array}$ & $\begin{array}{c}.0062 \\
(0.116) \\
\end{array}$ & $\begin{array}{c}.0129 \\
(0.252) \\
\end{array}$ \\
\hline $\begin{array}{c}\mathrm{N} \\
\text { Adj. R2 }\end{array}$ & $\begin{array}{c}45 \\
0.26\end{array}$ & $\begin{array}{c}45 \\
0.38\end{array}$ & $\begin{array}{c}45 \\
0.43\end{array}$ & $\begin{array}{c}45 \\
0.48\end{array}$ \\
\hline
\end{tabular}

t-statistics in parenthesis.

${ }^{*},{ }^{* *},{ }^{* *}$ imply significant at the 1,5 and $10 \%$ level.

\section{F. Description of the Data}

(i) Total Gross Domestic Product: Growth rates and logarithms of past values are per economically active population. It is calculated using the gross domestic product per capita constructed by the methodology developed in Summers and Heston [11] and updated in Summers and Heston [12]. This number is divided by the share of the economically active population in the total population given in World Bank [13].

(ii) Primary Exports/GNP, Agricultural Exports/GNP and Non-agricultural Exports/GNP: Calculated by using the primary exports and GNP figures given in World Bank [13]. 
(iii) Years Open: Percentage of years open in the period of reference. The number of years open is based on the criteria used in Sachs and Warner [6] to determine whether a country is open or not in a certain year.

(iv) Investment/GDP: Calculated using the values provided by Summers and Heston [12].

(v) Manufacturing and Services GDP: calculated using the figures of GDP described in (i) and the shares of the sectors given in World Bank [13].

(vi) Non-Resource Sector: Calculated using the data described on (i) and (ii).

(vii) "Real" Non-Resource Sector and "Real" Primary Exports Share: calculated using the data described in (i) and (ii) and the ratio of the deflators for merchandise exports and GDP given in World Bank [13].

(viii) Bureaucracy: Calculated using the Index of Bureaucracy Quality from Keefer, Philip and Stephen Knac (1995), “Institutions and Economic Policy: Cross-Country Tests Using Alternative Institutional Measures", Economics and Politics, VII, 207-227 (cited by Sachs and Warner [9]). The variable in this paper is equal to 6 (maximum possible value) minus the actual value of the index. A lower value means a higher quality of bureaucracy.

(ix) Fractionalization: Ethno-linguistic fractionalization. Taken from La Porta et al. [5].

(x) Credit Rationing: Total External Debt divided by the GNP for the countries which this ratio is available in World Bank [13]. These countries are all less developed countries. For OECD's countries this variable was set to zero (0).

(xi) Secondary Enrollment: Percentage of the age group attending secondary school. Taken from World Bank [13].

\section{References}

[1] Barro, Robert and Xavier Sala-i-Martin (1995), Economic Growth, McGraw-Hill, New York. 
[2] Caselli, Franceso, Gerardo Esquivel and Fernando Lefort (forthcoming), "Reopening the Convergence Debate: A New Look at the Cross-County Growth Empirics", Journal of Economic Growth.

[3] Davis Davis, Graham (1995), "Learning to Love the Dutch Disease: Evidence from Mineral Economies", World Development, 23, 1765-1779.

[4] Financial Times (various years), Financial Times International Yearbooks: Mining, Longmann, Essex.

[5] La Porta, Rafael, Florencio Lopez-de-Silanes, Andrei Shleifer and Robert Vishny (1998), "The Quality of Government", Mimeo, Harvard University.

[6] Manzano, O., Natural Resources, Taxation and Public Policy, Dissertation submitted to the Department of Economics at MIT as a part of the requirements to the fulfillment of the Ph.D. in Economics, MIT, Cambridge.

[7] Sachs, Jeffrey and Andrew Warner (1995a), "Economic Reform and the Process of Global Integration", Brookings Papers on Economic Activity, 25th anniversary issue, 1118.

[8] Sachs, Jeffrey and Andrew Warner, (1997a), "Natural Resource Abundance and Economic Growth", mimeo, Center for International Development, Harvard University.

[9] Sachs, Jeffrey and Andrew Warner (1997b), Natural Resource Abundance and Economic Growth, Data set available at http://www.cid.harvard.edu/data.htm

[10] OPEC (various years), Annual Statistical Bulletin, The Secretariat, Organization of Petroleum Exporting Countries, Vienna.

[11] Summers, Robert and Alan Heston (1991), "The Penn World Table (Mark 5): An Expanded Set of International Comparisons", Quarterly Journal of Economics, 106, 327-368.

[12] Summers, Robert and Alan Heston (1995), The Penn World Table (Mark 5.6), Data set available at http://pwt.econ.upenn.edu/

[13] World Bank (1999), World Development Indicators, (CD-ROM Data), Washington D.C. 